\title{
Managerial incentives to take asset risk
}

\author{
Marc Chesney, Jacob Stromberg, and Alexander F. Wagner*
}

March 10, 2018

\begin{abstract}
We argue that incentives to take equity risk ("equity incentives") only partially capture incentives to take asset risk ("asset incentives"). This is because leverage, while central to the theory of risk-shifting, is not explicitly considered by equity incentives. Employing measures of asset incentives that account for leverage, we find that asset risk-taking incentives can be large compared to incentives to increase firm value. Moreover, stock holdings can induce substantial risk-taking incentives, qualifying common beliefs regarding the central role of stock options. Finally, asset incentives help explain asset risk-taking of U.S. financial institutions before the 2007/08 crisis.
\end{abstract}

JEL-Code: G01, G28, G34

Keywords: Executive compensation; managerial incentives; risk-shifting; asset risk-taking; compound options; financial crisis; write-downs

\footnotetext{
* Chesney: University of Zurich. Stromberg: UBS. Wagner: Swiss Finance Institute, University of Zurich, CEPR, and ECGI. Contact information: alexander.wagner@bf.uzh.ch. We thank session participants at the Western Finance Association (WFA) 2011 meetings, the Swiss Winter Conference on Financial Intermediation (SWCFI) 2012, the Finance Down Under (FDU) conference 2012, the American Economic Association (AEA) 2017 meetings, and two Research Days of the SFI as well as seminar participants at BI Oslo, the University of Bern, and the University of Zurich for helpful discussions. Renée Adams (FDU discussant), Marc Arnold, Urs Birchler, François Degeorge, Rüdiger Fahlenbrach, Peter Fiechter, Francesco Franzoni (SFI discussant), Rajna Gibson, Denis Gromb, Seraina Grünewald, Michel Habib, Pedro Matos (WFA discussant), Aksel Mjos (SWCFI discussant), Tatjana-Xenia Puhan, Jean-Charles Rochet, Kelly Shue (AEA discussant), Lemma Senbet, and Christoph Wenk provided useful comments on earlier versions of the paper. Josefine Böhm and Patrick Quensel provided excellent research assistance. We also thank the Swiss Finance Institute, the NCCR FINRISK and the UZH Research Priority Programs "Finance and Financial Markets" and "Financial Market Regulation" for financial support. Wagner is an Independent Counsel for PricewaterhouseCoopers and chairman of SWIPRA. The views expressed in this paper fully reflect our own and not necessarily the views of PricewaterhouseCoopers, SWIPRA, or UBS. The authors declare that they have no relevant or material financial interests that relate to the research described in this paper.
} 


\section{Introduction}

This paper investigates managerial incentives to take asset risk. A significant theoretical literature deals with these incentives, offering the central insight that managerial compensation structures should "...take into account not only the agency relationship between shareholders and management, but also the conflicts of interests which arise in the other contracting relationships ..." (John and John, 1993, p. 950). Besides the manager-shareholder conflict, perhaps the most important conflict arising in the corporate "nexus of contracts" (Jensen and Meckling, 1976) is the shareholderbondholder conflict regarding "asset substitution." While shareholders want to align managerial interests with their own and also to shift risk to bondholders to some extent, they consider that asset risk-taking incentives optimally avoid excessive (firm value-reducing) agency costs of debt.

Although these ideas have long been theoretically established 1 little is known empirically about managerial incentives to take asset risk embedded in observed compensation contracts. This is surprising, given the great relevance of these incentives in corporate finance research (in particular, for work aiming to explain asset risk-taking by firms) and discussions in practice. This paper aims to make progress on this issue by addressing two questions: First, how powerful are a typical manager's incentives to take asset risk and to increase firm value? Second, can asset risk-taking incentives add to our understanding of the cross-sectional variation of asset risk-taking?

Section 2 deals with the first question. We consider a CEO who receives stock and/or stock options, the two most direct means of aligning shareholder and managerial interests. To understand the embedded incentives to take asset risk, we not only model equity itself as an option on the firm's assets (Merton, 1974), but, to be consistent, we also treat stock options as compound options on the underlying asset value (Geske, 1979). This combined approach is novel to the incentives literature.

In this framework, we calculate the following measures: Asset Volatility Vega is the dollar change of the value of a stock or stock option with respect to a 0.01 change in the asset return volatility, and Asset Delta is the dollar change of the value of a stock or stock option with respect to a one percent

\footnotetext{
${ }^{1}$ Other theoretical papers studying how optimal incentives navigate the two conflicts include, for example, Haugen and Senbet (1981) and John, Saunders, and Senbet (2000).
} 
change in the firm value. One auxiliary contribution of this paper is that we provide a correct formula for the sensitivity of a compound option to the volatility of the underlying (departing from the formula presented in Geske (1979)).

These two quantities capture asset incentives. We choose this terminology to emphasize that although the manager receives pay whose value depends on equity values, our measure captures his implied incentives to influence asset values and asset risk.

By contrast, Equity Volatility Vega measures the incentives of the CEO to increase stock return volatility. Equity Delta measures the incentives to increase the stock price. These two quantities, usually calculated as in Core and Guay (2002), have been widely used in the empirical literature on risk-taking and incentives. They form the equity incentives.

The critical difference between asset incentives and equity incentives is that the level of debt enters explicitly only in the calculations of asset incentives. To intuitively see why this is important when aiming to compare, across CEOs, incentives to take asset risk, note that the additional asset risk-taking that causes a 0.01 change in equity return volatility depends on leverage. This reflects the idea from the theory of asset substitution that managerial asset risk-taking incentives change as leverage changes. However, leverage does not feature explicitly in the calculation of equity incentives; therefore, equity incentives can indicate asset incentives, but the cross section of equity incentives only partially captures the cross section of asset incentives. More formally, for a given $\mathrm{CEO}$, asset volatility and equity volatility are linked through the elasticity of the equity value with respect to the asset value, and this elasticity varies (non-linearly) across firms as leverage varies. In the cross section of CEOs, asset incentives are, therefore, not simply a uniformly scaled version of equity incentives.

To develop this intuition and to explore the quantitative importance of the difference between the incentive measures in practice, we then consider a CEO receiving a compensation package of a given value, consisting of different combinations of stock and stock options. For an interpretation of the overall incentives to take asset risk embedded in a compensation package, we note that because the manager is risk-averse, higher exposure to firm value movements (due to a higher Asset Delta) 
makes the manager less willing to take asset risk. A meaningful measure of overall managerial asset substitution incentives is, therefore, given by the Asset Incentive Ratio, the ratio of total Asset Volatility Vega and total Asset Delta. Similarly, the Equity Incentive Ratio is the ratio of total Equity Volatility Vega and total Equity Delta. (In the empirical analysis, we consider these ratios, but we also always report results for the underlying two measures, vega and delta, separately.)

This basic analysis yields four results. First, the Asset Incentive Ratio suggests significant asset risk-taking incentives even when a CEO is compensated only with stock. Second, for all combinations of stock and stock options, the Asset Incentive Ratio is significantly higher than the Equity Incentive Ratio. Third, as expected, the difference between the Asset Incentive Ratio and the Equity Incentive Ratio is greater when leverage is higher; however, even at $40 \%$ leverage (the average leverage of a BBB-rated firm) the differences can be substantial. Fourth, the higher leverage is, the less stock options add in terms of asset risk-taking incentives (compared to equity risk-taking-incentives); intuitively, at high leverage, stock itself has such strong optionality that even a CEO holding only stock already has strong incentives to take asset risk, and the marginal contribution of stock options is, in fact, small.

In view of the important role that leverage plays for incentives, we then explore the relevance of asset risk-taking incentives in a sample of U.S. financial institutions. We are particularly interested in the years before the $2007 / 08$ financial crisis.

Here, too, we document several notable facts, which confirm in the data what the previous analysis had suggested for a hypothetical CEO. First, for many CEOs in the sample, incentives to take asset risk emanating from stock-holdings are substantial. In some contrast, relying on results from Guay (1999) for an average of firms over a range of industries, the existing literature argues that the incentives, due to stock holdings, to take equity risk are negligible. By setting Equity Volatility Vega from stock to zero, the literature effectively assumes that risk-taking incentives are due only to stock options. Practitioners also tend to perceive stock options as the main driver of risk-taking behavior by CEOs. Our theoretical and empirical findings qualify this view, and they have both practical implications for boards of directors designing managerial compensation systems 
and for academics conducting research on risk-taking. From a policy perspective, even if regulation is put in place that reduces financial leverage of financial institutions somewhat, the results imply that even straightforward equity plans entail significant asset risk-taking incentives.

Second, a puzzling fact in much of the literature is that the observed Equity Incentive Ratio is often fairly small - perhaps too small to offer an economic justification for a CEO to engage in significant risk-taking. For asset incentives, we obtain quite different results. In our sample, for the main parameter choice, the average CEO has an Asset Volatility Vega of around US\$3.5 million and an Asset Delta of around US\$6 million dollars. The Asset Incentive Ratio is, at the mean, about 0.50, around 30-50\% larger than the Equity Incentive Ratio. For other reasonable parameter values, this difference can be much larger.

Third, the correlation between the Asset Incentive Ratio and the Equity Incentive Ratio is on average only about 0.40 in our sample, even controlling for leverage. Thus, incorporating crosssectional variation in leverage into the calculation of incentives and recognizing that risk-taking incentives emanate also from stocks indeed yields a new perspective on incentives.

Section 3 then documents the potential empirical importance of considering managerial asset incentives when aiming to explain asset risk-taking, continuing to use the 2007/08 crisis as the context. We consider various measures of risk-taking. We note that this crisis essentially exposed the downside of the asset risk that banks undertook in prior years. As such, write-downs in 2007/08 form a natural indication of the degree of asset risk-taking by financial institutions in years prior to the crisis. Indeed, by and large, banks with higher Asset Incentive Ratios in the years 2003-06 had higher write-downs (both in absolute terms and scaled by total assets). Also, banks with stronger incentives to take asset risk tended to derive a larger portion of their income from non-interest activities and invested more in mortgage-backed securities and low-quality real estate. Moreover, the market recognized a higher expected default frequency of financial institutions with higher Asset Incentive Rations, that is, these companies exhibited smaller distance to default. Supplementary instrumental variable regressions suggest that endogeneity issues do not fully explain these results. In sum, asset incentives help explain variation in asset risk-taking by financial institutions. Interestingly, the 
Equity Incentive Ratio does not provide much explanatory power in our regressions, consistent with the intuition that to explain asset risk-taking it is important to use asset incentives.

Our paper contributes to two strands of the literature. First, the general literature on managerial compensation schemes and their consequences, which is too large to review in detail, mostly deals with incentives of the CEO to increase the share price and to take equity risk (see, for example, Coles, Daniel, and Naveen (2006), Guay (1999) and Knopf, Nam, and Thornton (2002)). The main contribution of this paper is to introduce and shed light on the relevance of managerial incentives to take asset risk and increase the firm value. The notion that such asset risk taking incentives emanate also from straight equity ownership does not contradict or make less relevant the idea that stock options can provide risk-taking incentives. For example, Shue and Townsend (2017) provide evidence of a causal effect of options on risk-taking. Our paper cautions, however, that an exclusive focus on stock options as the driver of risk-taking incentives can be problematic. Although asset substitution has been a central theme of corporate finance since Jensen and Meckling (1976), asset incentives have not received much attention 2

Second, this paper also makes a specific contribution to the financial crisis literature because our approach and, consequently, our results differ from other papers $3^{3}$ The related papers in this literature can be organized in terms of the dependent variable (risk-taking before the crisis or performance during the crisis) and the central explanatory variable (incentives or governance), as shown in the following matrix.

\footnotetext{
${ }^{2}$ We recently became aware of an independent paper (Anderson and Core 2016), which also studies incentives to increase firm volatility. While our papers share the basic idea that risk-taking incentives are also embedded in equity, there are many differences between our studies. Anderson and Core consider stock options as warrants and focus on the dilution that may occur when an option is exercised. Where they use post-2006 data, they can also compute incentives from inside debt. We consider stock options as compound options and posit that the option is either settled in cash or that the company has sufficient shares in its treasury to settle the option. We provide a closed-form solution for Asset Volatility Vega of stock options. In the empirical analysis of risk-taking, we also control for Asset Delta, while Anderson and Core present regression results using Equity Delta (which is correlated, but, as we show, not perfectly correlated with Asset Delta). Third, Anderson and Core study a wide sample of firms without financial institutions. We focus on financial institutions.

${ }^{3}$ For studies on risk-taking and governance in banks generally see, for example, Laeven and Levine (2009) and Saunders, Strock, and Travlos (1990). Faulkender, Kadyrzhanova, Prabhala, and Senbet (2010) survey some of the financial crisis literature. Theoretical models of optimal incentive design and regulation of pay especially in financially institutions are contained in, for example, see John, Saunders, and Senbet (2000), John, Mehran, and Qian (2010), Bebchuk and Spamann (2010), and Bolton, Mehran, and Shapiro (2015).
} 
The work listed in the four quadrants is as follows: First, some papers consider risk-taking and governance: Cheng, Hong, and Scheinkman (2015) document a positive association between total compensation and risk-exposure of financial institutions; other work focuses on corporate governance and specific measures of risk-taking, such as risky mortgage-backed securities involvement (Ellul and Yerramilli, 2013). Second, Adams (2012) considers the quality of governance in U.S. banks, while Erkens, Hung, and Matos (2012) primarily consider the relation between various measures of performance and corporate governance in a global sample. (They also provide results regarding risk-taking.) Third, Fahlenbrach and Stulz (2011) study the correlation of performance measures, stock returns and returns on assets, with equity incentives.

\section{Selection of related empirical papers in the financial crisis literature}

\begin{tabular}{c|c|c} 
& Risk-Taking & Performance \\
\hline Incentives & DeYoung, Peng, and Yan (2013) & Fahlenbrach and Stulz (2011) \\
& This papr & Erkens, Hung und Matos (2012) \\
Governance & $\begin{array}{c}\text { Cheng, Hong, and Scheinkman (2015) } \\
\text { Ellul and Yerramilli (2013) }\end{array}$ & $\begin{array}{c}\text { Adams } \\
\end{array}$
\end{tabular}

Fourth, DeYoung, Peng, and Yan (2013) consider the relationship between incentives and risktaking. They provide a rich set of evidence. Of particular interest, in relation to our analysis, are their results on asset risk-taking. They find that both Equity Volatility Vega and Equity Delta were positively associated with investments in MBS securities in the years before the crisis. As they note, this finding is puzzling. Theoretical considerations and previous empirical evidence suggest that Vega and Delta should be associated with risk-taking with opposite signs (e.g., Knopf, Nam, and Thornton (2002) ) ${ }^{4}$ Our analysis provides empirical support for this idea in the context of the 2007/08 financial crisis.

\footnotetext{
${ }^{4}$ In an earlier working paper version, De Young, Peng and Yan looked at an even broader range of asset risk variables, for example, bank investments in commercial real estate and mortgages. Like MBS investments, these other variables are arguably related to our summary measure, write-downs. However, they obtained mixed results with these variables. For two summary equity risk measures (systematic equity risk and idiosyncratic equity risk) DeYoung, Peng, and Yan (2013) find a positive relation with Equity Volatility Vega and a negative relation with Equity Delta, consistent with theoretical predictions.
} 


\section{Managerial Asset Incentives}

We consider a CEO who receives equity-based compensation, consisting of stock and/or stock options. To measure managerial incentives to take asset risks, we appeal to the idea, dating back to Merton (1974), that equity can be viewed as a contingent claim on the firm value. Using this framework, we calculate asset incentives, Asset Volatility Vega - capturing the incentives to increase the standard deviation of firm value - and Asset Delta - capturing the incentives to increase firm value. Guay (1999) also relies on the contingent claims idea to calculate, for a sample of firms including both financial and non-financial companies, the Equity Volatility Vega of stock. However, Guay (1999) then goes on to calculate Equity Volatility Vega from stock options in the usual way, relying on the Black-Scholes formula, treating equity as the primitive, and then adds to this the Equity Volatility Vega from stocks obtained by relevering his Asset Volatility Vega of stocks. We instead consider stock options as compound options (Geske, 1979). The idea of considering stock options as compound options on the firm value is new to the literature on risk-taking, but a natural step in order to operate within a coherent framework.

Subsection 2.1 sets up the model framework. Subsection 2.2 derives Asset Delta and Asset

Volatility Vega. Subsection 2.3 introduces Equity Delta and Equity Volatility Vega. Subsection 2.4 explains the differences of asset incentives and equity incentives for the case of a single stock or stock option. Subsection 2.5 investigates the incentives emanating from a portfolio of stocks and stock options. Subsection 2.6 provides a quantitative analysis of managerial incentives to take asset risk in a cross section of financial institutions.

\section{1 $\quad$ Model}

We follow Merton (1974) and assume the firm value, $V$, follows a geometric Brownian motion

$$
\frac{d V_{t}}{V_{t}}=\mu_{V} d t+\sigma_{V} d W_{t}
$$


where $\left\{W_{t}\right\}_{t \geq 0}$ is a standard Brownian motion under the historical measure. The parameters $\mu_{V}$ and $\sigma_{V}$ are assumed constant. We also assume that there exists a bank account which yields a constant interest rate $r$. Considering equity as a call option on the firm value, stock can be valued according to the Black-Scholes formula

$$
\mathrm{BS}_{0}:=S_{0}=V_{0} N\left(d_{1}\right)-D e^{-r T_{D}} N\left(d_{2}\right)
$$

where $d_{1}=\frac{\ln \left(V_{0} / D\right)+\left(r+\sigma_{V}^{2} / 2\right) T_{D}}{\sigma_{V} \sqrt{T_{D}}}$ and $d_{2}=d_{1}-\sigma_{V} \sqrt{T_{D}}$.

Next, we recognize that stock options can be viewed as compound options on the underlying firm value $V$. This idea is novel to the executive incentives literature. Geske (1979) shows that the price of a compound call (CC) option is given by

$$
\begin{aligned}
\mathrm{CC}\left(V, D, r, T_{C C}, T_{D}, \sigma_{V}, K\right) & =V N_{2}\left(h+\sigma_{V} \sqrt{T_{C C}}, k+\sigma_{V} \sqrt{T_{D}} ; \sqrt{T_{C C} / T_{D}}\right) \\
& -D e^{-r T_{D}} N_{2}\left(h, k ; \sqrt{T_{C C} / T_{D}}\right)-K e^{-r T_{C C}} N_{1}(h),
\end{aligned}
$$

where $N_{2}(\cdot)$ represents the bivariate cumulative normal distribution function, $N_{1}(\cdot)$ represents the standard normal cumulative distribution function, $T_{C C}$ denotes the expiration of the stock option and $T_{D}$ denotes the maturity of the debt 7 The remaining terms are

$$
h=\frac{\ln (V / \bar{V})+\left(r-\frac{1}{2} \sigma_{V}^{2}\right) T_{C C}}{\sigma_{V} \sqrt{T_{C C}}}, \quad \text { and } \quad k=\frac{\ln (V / D)+\left(r-\frac{1}{2} \sigma_{V}^{2}\right) T_{D}}{\sigma_{V} \sqrt{T_{D}}}
$$

and $\bar{V}$ is the value of $V$ which is the implicit solution to the equation

$$
V N_{1}\left(\bar{k}(V)+\sigma_{V} \sqrt{T_{D}-T_{C C}}\right)-D e^{-r\left(T_{D}-T_{C C}\right)} N_{1}(\bar{k}(V))-K=0,
$$

\footnotetext{
${ }^{5}$ We exclude dividends for simplicity. From option pricing theory there is no reason to expect that omitting this component will result in substantially different outcomes.

${ }^{6}$ From here on, we omit the time subscripts for notational simplicity.

${ }^{7}$ Thus, the model requires that $T_{D}>T_{C C}$. We come back to the choice of appropriate debt and stock option maturities in our application below.
} 
where

$$
\bar{k}(V)=\frac{\ln (V / D)+\left(r-\frac{1}{2} \sigma_{V}^{2}\right)\left(T_{D}-T_{C C}\right)}{\sigma_{V} \sqrt{T_{D}-T_{C C}}}
$$

and where $K$ denotes the strike price of the option and $D$ denotes the face value of debt per share, so that $\bar{V}$ denotes the firm value where the option is just at the money at time $T_{C C}$.

\section{$2.2 \quad$ Asset Incentives}

We now compute sensitivities of a single stock and a single stock option with respect to firm value parameters. Asset Delta is the first derivative of the stock and stock option price, respectively, with respect to a one percent change in the firm value, $V$. Asset Volatility Vega is the first derivative of the stock and stock option price, respectively, with respect to a 0.01 change in the underlying asset return volatility, $\sigma_{V}$.

First, the sensitivity of a stock with respect to a change in firm value is

$$
\begin{aligned}
\text { Asset Delta from stocks } & =\frac{\partial \mathrm{BS}_{0}\left(V, D, r, T_{D}, \sigma_{V}\right)}{\partial V} \cdot(V / 100) \\
& =N\left(d_{1}\left(V, D, r, T_{D}, \sigma_{V}\right)\right) \cdot(V / 100) .
\end{aligned}
$$

Note that Asset Delta from stocks is not equal to one.

Second, by relying on the formula for a compound call option,

$$
\begin{aligned}
\text { Asset Delta from stock options } & =\frac{\partial \mathrm{CC}\left(V, D, r, T_{C C}, T_{D}, \sigma_{V}, K\right)}{\partial V} \cdot(V / 100) \\
& =N_{2}\left(h+\sigma_{V} \sqrt{T_{C C}}, k+\sigma_{V} \sqrt{T_{D}}, \sqrt{T_{C C} / T_{D}}\right) \cdot(V / 100) .
\end{aligned}
$$

Note that the derivative of the compound formula with respect to the underlying asset value, $V$, converges to the Delta in the Black-Scholes model as the face value of debt equals zero.

Third, we compute the incentive, coming from the CEO's stock holdings, to increase the firm 
value return volatility. Relying on the Black-Scholes formula, we obtain

$$
\begin{aligned}
\text { Asset Volatility Vega from stocks } & =\frac{\partial \mathrm{BS}_{0}\left(V, D, r, T_{D}, \sigma_{V}\right)}{\partial \sigma_{V}} \cdot(1 / 100) \\
& =\varphi\left(d_{1}\left(V, D, r, T_{D}, \sigma_{V}\right)\right) V \sqrt{T_{D}} \cdot(1 / 100)
\end{aligned}
$$

where $\varphi$ denotes the standard normal probability density.

Fourth, we turn to the incentive, coming from the CEO's stock option holdings, to increase the firm value return volatility. For this sensitivity, we derive the result in Proposition 1.

Proposition 1. The Asset Volatility Vega of a stock option in the compound option pricing model is given by

$$
\text { Asset Volatility Vega from stock options }=\frac{\partial C C\left(V, D, r, T_{C C}, T_{D}, \sigma_{V}, K\right)}{\partial \sigma_{V}} \cdot(1 / 100)
$$

where

$$
\begin{aligned}
\frac{\partial C C\left(V, D, r, T_{C C}, T_{D}, \sigma_{V}, K\right)}{\partial \sigma_{V}} & =V \varphi\left(h+\sigma_{V} \sqrt{T_{C C}}\right) \sqrt{T_{C C}} N_{1}\left(\bar{k}(\bar{V})+\sigma_{V} \sqrt{T_{D}-T_{C C}}\right) \\
& +D e^{-r T_{D}} \varphi(k) \sqrt{T_{D}} N_{1}\left(\frac{h-\sqrt{\frac{T_{C C}}{T_{D}}} k}{\sqrt{1-\frac{T_{C C}}{T_{D}}}}\right)
\end{aligned}
$$

and the parameters are defined in Section I.A.

Proof See Appendix A.

Contrary to the result presented in Geske (1979), which is shown in Appendix A for completeness, our formula for the derivative of the compound option value with respect to the asset return volatility converges to the Black-Scholes Vega as the debt converges to zero. Indeed, this appears to be the intuitive benchmark result. In the formula of Geske (1979), vega goes to zero for zero debt. More importantly, even for non-zero debt there are often substantial differences in the magnitude of the calculated risk-taking incentives using both approaches. This is illustrated in Figure 1 . The figure considers a single stock option. We plot the Asset Volatility Vega using the formula 
in Geske (1979) and the formula given in Proposition 1. Figure 1 also shows a discrete difference approximation using the compound option pricing formula derived by Geske (1979) $\left.\right|^{8}$ Notably, this difference approximation agrees with our analytical formula for the Asset Volatility Vega given in Proposition 1.

\section{FIGURE1] ABOUT HERE}

For the chosen parameters and a face value of debt of 85 (which implies leverage of around $55 \%$ ), a single compound call option on the stock is worth US\$ 11.5. For this case, we observe an Asset Volatility Vega (from a single stock option) of around US\$ 0.94 based on Proposition 1, whereas the equivalent Asset Volatility Vega based on the formula presented in Geske (1979) equals US\$ 0.12 .

Naturally, at very high leverage levels, when the compound option is deep out of the money, increases in the asset volatility induce small value changes in the option value, resulting in the same hump-shape form of Asset Volatility Vega of a single stock option with respect to the debt level that arises also for a stock option with respect to the stock option strike price. Asset Volatility Vega of a single option is monotonically increasing in the underlying asset volatility; see Figure A-1. in the Appendix.

Next, we consider a portfolio of options. Consider a board that is given the CEO compensation in the form of stock options of a given amount. (For example, compensation consultants may have advised the board that this is the appropriate level of equity-based incentive compensation.) How do asset incentives change depending on the financial leverage of the company? Figure 2 shows that both the whole portfolio's Asset Volatility Vega and the Asset Delta are increasing in leverage. As leverage increases, an increasing number of options has to be given to the CEO in order to keep the value of the options constant. This dominates the hump-shaped relationship between leverage and Asset Volatility Vega found for a single stock option in Figure 1. Importantly, Figure 2 shows

\footnotetext{
${ }^{8}$ That is, we approximate the derivative of the compound call option price with respect to $\sigma_{V}$ with a first difference of the compound option pricing formula with respect to $\sigma_{V}$. For this, we consider a sufficiently small change in $\sigma_{V}$ in order to approximate the true derivative with a high precision.
} 
that the relationship between leverage and Asset Volatility Vega differs from that between leverage and Asset Delta 9

\section{FIGURE 2 ABOUT HERE}

\subsection{Equity Incentives}

An alternative way to quantify managerial incentives is to consider the sensitivities of CEO wealth to the stock price level and stock return volatility, respectively. Equity Delta is the sensitivity of a stock or stock option with respect to a one percent change in the company's underlying stock price. Equity Volatility Vega is the change in the dollar value of a stock or stock option in response to a one percentage point change in stock return volatility based on the Black-Scholes option pricing formula. Following Core and Guay (2002) and most of the existing literature, we assume that the Equity Volatility Vega from shares of stock equals zero. See Appendix B for details.

\subsection{Comparing Asset Incentives and Equity Incentives}

Asset incentives depend explicitly on the level of leverage, consistent with the central insight of Jensen and Meckling (1976) that asset substitution incentives increase with leverage. By contrast, leverage does not enter explicitly into the formulas determining equity incentives shown in Appendix B. Thus, Equity Delta for stock is unity, but Asset Delta is less than unity. Conversely, Asset Volatility Vega is greater than Equity Volatility Vega. For a given firm (at a given leverage), the latter result is merely a reflection of the fact that equity volatility is determined by asset volatility, multiplied by the elasticity of the equity value with respect to the asset value $\left(\sigma_{S}=\right.$ $\left.\sigma_{V}(d S / S) /(d V / V)\right)$. This elasticity is greater than one. Importantly, it is a (non-linear) function of

\footnotetext{
${ }^{9}$ Note that in the figure we are fixing debt volatility. This is used to infer equity volatility (as asset volatility is taken as given). This in turn affects the number of options at each point in the figure. Naturally, as leverage changes, one might expect debt volatility to change. In the type of data we are considering in the empirical analysis, leverage is around $90 \%$ on average. In applications where there is a broad range of leverage in the data, using different levels of debt volatility (for example, from different bond indices) can be important. Qualitatively very similar results obtain when valuing the stock option as a compound option value and thus keeping the compound value constant as leverage changes.
} 
leverage; thus, it varies across firms. In the cross section of firms with varying degrees of leverage this fact induces a critical difference between asset incentives and equity incentives.

Intuitively, when working with equity incentives, an increase in equity volatility by 0.01 can come about from different increases of asset risk for each CEO because firms differ in leverage. (And, because leverage matters non-linearly for asset incentives, controlling for leverage in a linear regression may not suffice.) Thus, the cross section of incentives to take equity risk yields limited insight into the cross section of CEO incentives to take asset risk. Considering asset incentives, instead, "normalizes" the incentive measure in the sense that an increase of asset volatility by 0.01 means the same for each $\mathrm{CEO} 10$ The following two subsections develop this intuition in more detail and explore its quantitative importance in practice.

\subsection{Incentives From a Portfolio of Stock and Stock Options}

Consider a board that provides a $\mathrm{CEO}$ with an equity-based compensation package. The package should have some given value (say, US\$ 5 million, though this value is irrelevant for the analysis that follows). The total Vegas and Deltas are obtained by multiplying the single stock and single stock option Vegas and Deltas by the numbers of stocks and stock options conveyed to the CEO. What are the implied managerial asset substitution incentives of different combinations of stock and stock options, holding the overall value of the compensation package constant?

To analyze this issue in a condensed fashion, we begin by noting that, everything else equal, asset risk-taking incentives are higher if Asset Volatility Vega is higher. In addition, a risk-averse CEO wishes to avoid fluctuations in the asset value, and this desire is more pronounced the more he participates in any upward or downward movement of firm value. Therefore, asset risk-taking incentives are lower if Asset Delta is higher 11 CEOs are far less risk-averse than the general population (Graham, Harvey, and Puri, 2013). Nonetheless, because Asset Volatility Vega and

\footnotetext{
${ }^{10}$ Of course, it may be more difficult for some CEOs to achieve such an increase than for others, but that is not a matter of incentives, but a matter of cost of effort.

${ }^{11}$ For equity incentives, the prediction is somewhat ambiguous. A higher Equity Delta may also induce more risk-taking because risk-taking may shift asset risk and can thus make equity holders better off.
} 
Asset Delta typically move together, both effects need to be considered ${ }^{12}$ In the spirit of Dittmann, Yu, and Zhang (2017), we therefore define the Asset Incentive Ratio as the ratio of Asset Volatility Vega and Asset Delta. This provides a useful summary measure of incentives for our purposes ${ }^{13}$ Similarly, the Equity Incentive Ratio is the ratio of Equity Volatility Vega and Equity Delta.

Figure 3 shows three lines each for the Asset and Equity Incentive Ratio, using different levels of leverage ${ }^{14}$ Several properties of the incentive ratios are noteworthy.

\section{FIGURE 3 ABOUT HERE}

First, the intercept of the Asset Incentive Ratio line is above zero - consistent with the fact that the asset view allows for risk-taking incentives to emanate also from stock holdings. Naturally, the intercept is higher for higher leverage.

Second, the Asset Incentive Ratio is larger than the Equity Incentive Ratio. In other words, asset risk-taking incentives can be large relative to incentives to increase firm value, even when incentives to take equity risk are dwarfed by incentives to increase the stock price ${ }^{15}$

Third, over the whole range of portfolio combinations, as leverage increases, asset substitution incentives for managers become more pronounced and the difference between the Asset Incentive Ratio and the Equity Incentive Ratio becomes bigger. (The same is naturally also true for higher asset volatility; this result is not shown in the graph.) For high leverage, the Asset Incentive Ratio is easily greater than unity, while this only occurs in extreme cases for the Equity Incentive Ratio.

\footnotetext{
${ }^{12} \operatorname{Ross}$ (2004) formally shows that while options have a "convexity effect", options also increase the sensitivity of the owner's wealth to the underlying, which may lead a risk-averse option owner to want to decrease the underlying risk. Lambert, Larcker, and Verrecchia (1991), Ingersoll (2006), and Carpenter (2000) also argue that a risk-averse and under-diversified manager may adopt risk-reducing policy choices when compensation exhibits high pay-performance sensitivity.

${ }^{13}$ An alternative way to incorporate risk aversion would be to directly model expected utility of the agent, but this would require assumptions regarding executives' utility functions.

${ }^{14}$ Equity incentives do not directly depend on leverage. However, as leverage changes, so does the implied equity volatility, and therefore the number of shares and options conveyed to the CEO also changes to keep the overall value of the compensation package constant.

${ }^{15}$ Of course, the ratios themselves cannot be directly compared as the underlying moving parts differ - asset values and asset volatility in one case, equity values and equity volatility in the other case. The point is that they tell quantitatively different stories related to the manager's incentives to increase the underlying's value relative to increase the risk of the underlying.
} 
Fourth, when stock options make up a larger fraction of the portfolio of the CEO, the overall risk-taking incentives, measured by the two incentive ratios, increase. But the role of stock options varies between asset incentives and equity incentives. For example, starting at $80 \%$ stock and $20 \%$ stock options and going to $20 \%$ stock and $80 \%$ stock options, the Equity Incentive Ratio goes up by a factor of three. By contrast, for the same change in the composition of the pay package the Asset Incentive Ratio only approximately doubles (in the case of leverage of $40 \%$ and $55 \%$ ) or increases by only about $40 \%$ (in the case of leverage of $70 \%$ ). This result can be explained by recognizing that when leverage is higher, stock itself already incorporates a significant optionality (reflected in the higher intercept), so that the extra optionality introduced by the compound option adds relatively little to the overall asset risk-taking incentives 16

\subsection{The Cross Section of CEO Incentives in Financial Institutions}

We have seen that, consistent with intuition, asset substitution incentives of CEOs are likely to become particularly pronounced at high leverage. We now study a group of firms for which leverage is a central characteristic: financial institutions. Indeed, understanding incentives of managers in the financial services industry is of particular interest in the light of recent events.

The sample in which we study this issue includes depository institutions, non-depository credit institutions, and investment banks and some brokerage firms. We refer to all companies in our sample as financial institutions ${ }^{17}$ We require a company to have compensation data available in the ExecuComp database. We focus on the years 2003 to 2006 because, as we explain further below, these years are most likely to contain information regarding the incentives of managers related to asset risk-taking that became relevant in the crisis. We also require that the company is alive at the beginning of the third quarter of 2007. Companies which did not have a stock price observation

\footnotetext{
${ }^{16}$ One can also verify that, when leverage is higher, the maximum difference between the Asset Incentive Ratio and the Equity Incentive Ratio occurs at a lower fraction of stock options.

${ }^{17}$ The sample choice is motivated by the empirical analysis of asset risk-taking by financial institutions that we conduct later. Table C-1 in the Supplementary Appendix displays the SIC codes we consider in the analysis. Nagel and Purnanandam (2015) highlight that for banks, assets embed a short put option on the borrowers' assets. Thus, assets themselves are options, which would make equity a compound option and stock options a triple compound option. Our model must abstract from this additional complication. We focus on asset risk-taking where there is also an upside for the financial institution taking the risk.
} 
in CRSP for July 2007 are deemed inactive and excluded from our analysis. However, companies remaining on this list are allowed to subsequently default, be taken over by or merged with another company during the crisis period ${ }^{18}$

\subsubsection{Inputs}

Information about executive compensation pay packages is available annually for U.S. entities in Standard \& Poor's ExecuComp database. We focus our analysis on the CEO ${ }^{19}$ Consistent with existing literature, we define the inputs for our calculations as follows: (1) The stock options exercise prices and (2) maturities are taken from ExecuComp to the extent these are available. If the exercise price for granted stock options is not available, we assume they were granted at-the-money. To obtain the stock option maturity for missing grant dates, we follow Guay (1999) and calculate the maturity of the stock options by assuming that the stock options were granted on July 1 of the year in which the stock options were granted. (3) We use the fiscal year end closing price of the given year as the current stock price. (4) The stock return volatility is calculated (from CRSP data) as the annualized standard deviation of daily log-returns over the past three years by assuming 250 trading days in the year. (5) We use the U.S. Treasury yields obtained from the Fed's webpage as proxies for the risk-free interest rate. (6) The annual cash dividend paid by the company over the fiscal year end closing price is used to calculate the dividend yield. This information is also from CRSP.

For the asset incentives, we follow Guay (1999) in the calculations of the implied firm value and other parameters needed for the calculation of incentives. In particular, (7) the firm value (return) volatility is determined through a portfolio relationship with stock volatility and debt volatility (see Appendix C for details). For the standard deviation of debt returns, we use the annualized

\footnotetext{
${ }^{18}$ Some companies were too small to remain in the ExecuComp database for all years 2003 to 2006 but were still alive going into July 2007. Their compensation information is included into the analysis for the year(s) when they are covered in the ExecuComp database.

${ }^{19}$ Murphy (2011) argues that incentives of traders were more important than those of CEOs. Data on belowmanagement-level compensation structures are not broadly available, unfortunately. For years with missing CEO information and where the dates at which the CEO assumed office is prior to the particular year, we classify the executive as the CEO accordingly. If the CEO is not recorded and the necessary information is not accessible from the SEC Edgar database, we do not include the respective firm in the analysis.
} 
standard deviation calculated on monthly (log) returns using the Merrill Lynch Bank of America corporate financial bond index using a five year period ${ }^{20}$ As in Guay (1999), (8) the strike price for equity, seen as an option on firm value, is the book value of debt per share. (9) Guay (1999) assumes for financial firms that they have a single debt obligation with time to maturity equal to 7.5 years (as for most financial firms maturity data is unavailable). We use the same baseline assumption ${ }^{21}$ Together with the observation that the stock can be considered as a call option on the firm value, one can finally back out (10) an implied firm value per share. Table C-1 shows descriptive statistics for all the relevant variables.

Delta and Vega for previously granted options (i.e., exercisable and un-exercisable options) and current year granted options are then multiplied by the amount of options held by the CEO in each of these dimensions to form the final Vega and Delta quantities.

\subsubsection{Asset and Equity Incentives in Financial Institutions}

As a benchmark, we begin by analyzing the results for equity incentives. As seen in Table 2, the average Equity Volatility Vega implies that a one percentage point increase in the company's stock price volatility is associated with an increase of around US\$301,000 in CEO wealth. This number is comparable in size with that of other studies on risk-taking incentives in banks. While Equity Volatility Vega in financial institutions is about double the size of Equity Volatility Vega in the Coles, Daniel, and Naveen (2006) sample of industrial firms, it still seems modest, in particular

\footnotetext{
${ }^{20}$ We believe that this index fits our purposes better than the general Merrill Lynch Bank of America corporate bond index that matches the S\&P senior debt rating which Guay (1999) uses. With the index used in Guay (1999), we obtain stronger results both in terms of the size of risk-taking incentives and the statistical significance in our risk-taking regressions. Finally, the approach used in Gropp and Heider (2010), just delevering stock return volatility, yields very similar overall results, too.

${ }^{21}$ Core deposits (in addition to long-term debt as funding channels in financial institutions) have no explicit maturity and are often referred to as non-maturity debt. As pointed out by Sheehan (2004) such deposits often remain within the financial institution for significant periods of time, often longer than 10 years. Thus, 7.5 years is a reasonable approximation. Note that the debt maturity needs to be longer than the stock option maturity in order for the compound option approach to apply. In practice, stock option maturities typically range from 3 to 10 years. In cases where the stock option maturity is longer than 7.5 years, we set the maturity of debt equal to the stock option maturity plus two years. That is, for a stock option with a 10 year maturity, we effectively assume that the debt maturity is 12 years. However, consistent with Guay's (1999) assessment of the sensitivity of his results for Asset Volatility Vega from stocks to assumptions about debt maturity, we find that for Asset Volatility Vega from options, the results do not appear sensitive to how we adjust the debt maturity either.
} 
compared to Equity Delta. A 1\% increase in the company's stock price results in an increase of around US\$1,131,000 in the CEO's wealth on average. The Equity Incentive Ratio, defined as the ratio of Equity Volatility Vega and Equity Delta, is 0.30 on average.

However, it would be wrong to conclude, on the basis of evidence from equity incentives, that the wealth-driven incentives of CEOs to engage in risky activities, such as investing in sub-prime products, is small. The Asset Incentive Ratio, that is, the ratio of Asset Volatility Vega to Asset Delta, equals 0.44 at the median and is, as such, about 50\% larger than the Equity Incentive Ratio. Interestingly, the correlation between the Asset Incentive Ratio with the Equity Incentive Ratio is only around 0.36. The correlation of Asset Volatility Vega with Equity Volatility Vega is only 0.44 in the overall sample (0.38 to 0.53 across the years). The correlation of Asset Delta and Equity Delta is substantially higher, around 0.9 overall, but hardly perfect either. This set of results reflects the fact that, as explained in Subsection 2.4, asset incentives explicitly take into account leverage. Even after controlling for leverage, the partial correlation of Asset Volatility Vega with Equity Volatility Vega is only 0.43, suggesting that a linear control for leverage while using equity incentives as an explanatory variable for asset risk-taking is unlikely to produce the same results as using asset incentives.

Table 2 also shows that, as expected, a large part of asset risk-taking incentives continues to come from stock options, but it is clear that stock holdings can also imply significant asset risk-taking incentives. For the median CEO, asset risk-taking incentives due to options are large compared to those due to stock, but for the mean CEO, (only) about $60 \%$ of the total incentives to increase the asset return volatility are due to options. Table 3 confirms that the results holds across the years under consideration.

At higher asset volatilities, these effects are even more pronounced. This can be important because it is often argued that in recessions asset volatilities increase, suggesting particularly powerful asset risk-taking incentives of managers in bad times, relative to incentives to increase firm value. For instance, using debt volatilities proposed by Guay (1999) in his analysis (which covers both financials and industrial firms) yields somewhat higher asset volatilities and, consequently, ratios 
of Asset Vega Volatility to Asset Delta that are easily twice or three times as large as the ratios of Equity Volatility Vega and Equity Delta.

\section{TABLES 2 AND 3 ABOUT HERE}

In sum, considering incentives to take asset risk yields a novel picture of managerial risktaking incentives and may, therefore, contribute to an enhanced understanding of the relationship of incentives with risk-taking. We explore this potential in the next section.

\section{Incentives, Asset Risk-Taking, and the Financial Crisis of 2007/08}

The Board of Governors of the Federal Reserve System (2011) begins its review of incentive compensation practices with the simple statement: "Risk-taking incentives provided by incentive compensation arrangements in the financial services industry were a contributing factor to the financial crisis that began in 2007" (p. 1). Even some of those whose pay is being heavily regulated seem to agree that compensation systems played a role 22

In this section, we study the relation between incentives of CEOs and asset risk-taking before the crisis of $2007 / 08$.

\subsection{Hypotheses, Empirical Strategy, and Data}

It is important to note at the outset that shareholders in principle (ex-ante) welcomed the asset risktaking that later turned out to be harmful to the health of their financial institutions. For example, holding AAA tranches of securitized loans was appealing to shareholders for two reasons. First, these tranches paid extra yields over and above the typical AAA investments. Second, whether held on or off the balance sheet, these investments did not require backing by enhanced equity capital. ${ }^{23}$

\footnotetext{
${ }^{22}$ For example, in May 2008, PricewaterhouseCoopers and the Economist Intelligence Unit conducted a global survey of financial services industry executives and commentators. Asked which factors have created the conditions for the credit/banking crisis, only $31 \%$ of survey participants put the blame on "monetary policy," but an impressive $70 \%$ on "reward systems." See PricewaterhouseCoopers (2008).

${ }^{23}$ Whether equity is "expensive" is debated hotly. These discussions notwithstanding, it is a fact that most practitioners did believe that holding more equity was not desirable.
} 
Thus, to the extent that there are factors apart from material rewards that make CEOs act in the interest of shareholders, part of the asset risk-taking in banks, as in other corporations, will not be explained by direct monetary incentives of CEOs. Functioning alignment of CEO actions with shareholder interests in financial institutions thus generates a baseline amount of asset risk-taking ${ }^{24}$

What we are interested in is whether part of the variation in asset risk-taking beyond this baseline level can be explained by incentives embedded in the equity and stock option holdings of managers. Building on the earlier considerations (see Section 2.5), we test three main hypotheses regarding this relation.

Hypothesis 1: Asset Volatility Vega is positively associated with asset risk-taking.

Hypothesis 2: Asset Delta is negatively associated with asset risk-taking.

Hypothesis 3: The Asset Incentive Ratio is positively associated with asset risk-taking.

We use several empirical strategies to test these hypotheses: We run cross-sectional and panel regressions with various measures of asset risk-taking as the dependent variables. While write-downs are analyzed in cross-sectional regressions, other variables afford the opportunity for employing panel methods, thus also using firm fixed effects.

Risk-taking incentives, governance features, and other firm-specific variables serve as explanatory variables.

We first explain the choice of our dependent variables (Subsection 3.1.1). We next describe the explanatory variables (Subsection 3.1.2). Subsection 3.1.3 then discusses issues related to endogeneity problems in the relationship between asset risk-taking incentives and asset risk-taking.

An overview of all dependent and explanatory variables is contained in Table 1

\section{TABLE 1 ABOUT HERE}

\footnotetext{
${ }^{24}$ Of course, some ex post realizations also cover simply bad business choices, even those that were not considered risky ex-ante. For example, the practice of making "Ninja" (no income, no job, no asset) loans on the sheer hope that real estate prices would continue climbing was arguably ex-ante questionable. But not all risks that were taken can be labeled as ex-ante bad. Related to this question, there is some discussion as to just how much CEOs suffered from the crisis. On the one hand, Bebchuk, Cohen, and Spamann (2010) show that management teams in the case of Bear Stearns and Lehman Brothers were able to cash out large amounts of bonus compensation before the crisis. On the other hand, some evidence suggests that in general CEOs did not take actions they thought would be on average value-destroying and that they did not, on average, anticipate the crisis. For example, they did not sell their own shares prior to the crisis, see Fahlenbrach and Stulz (2011).
} 


\subsubsection{Dependent Variables}

Like other studies (Coles, Daniel, and Naveen, 2006, Guay, 1999, Hayes, Lemmon, and Qiu, 2012, Sanders and Hambrick, 2007), several of our empirical tests rely upon ex-post evidence of asset risk-taking, though we also consider some contemporaneous measures of risk-taking.

Write-Downs: For our first measure of risk-taking, the idea we appeal to is that for a given expected project value, a CEO with higher incentives to take risk will be willing to tolerate a greater spread in potential outcomes. Because the financial crisis exposed the downside of the investments that banks undertook in prior years, the write-downs form an indication of the degree of asset risk-taking. Because we aim to capture as broadly as possible the potential downsides, we focus on write-downs during the period 2007Q3-2008Q4. We collect write-downs data for all U.S. financial institutions for which they are available and for which we have compensation data from ExecuComp.

For the largest U.S. financial institutions these write-downs are available from Bloomberg, covering write-downs, losses, and loan-loss provisions. For the smaller U.S. financial institutions for which Bloomberg does not record write-downs we consult the companies' proxy filings (10-K and 10-Q). In particular, we identify the following components from the SEC filings in order to be as consistent as possible with the figures reported by Bloomberg: (1) Write-downs which are explicitly referred to as such. They cover charge-offs on loans (conditional on the fact that these are not included in the loan loss provisions). Furthermore, as a consequence of the financial crisis, some companies had to abandon certain development projects which led to rising severance charges. These are typically reported as specific write-downs related to the crisis. (2) Loan loss provisions are charges or expenses against income and loans which are deemed to be uncollectible due to the impact of the credit deterioration during the crisis period. (3) Subprime losses appear when companies directly state that certain losses have occured specifically due to, e.g., investments in the subprime mortgage backed security market or due to the bankruptcies of Fannie Mae and Freddie Mac. (4) Impairment charges (or impairment on securities) are non-temporary impairments on 
held to maturity and available for sale securities. This is sometimes referred to as losses on trading securities or impairment on real estate investments. (5) Credit losses which are directly referred to as such but are not included in the loan loss provisions.

We use both write-downs scaled by total assets to investigate the relative level of asset risktaking and the logarithm of write-downs to study the absolute (dollar level) of asset risk-taking (controlling, of course, for firm size).

Advantages and Disadvantages of Write-downs and Alternative Measures: Write-downs form a natural proxy for the ex-ante asset risk-taking of financial institutions precisely because they are not only realized losses, but also unrealized losses. Even if assets that are held to maturity in the end do not lead to an actual loss, the fact that banks had to take write-downs on them indicates their ex-ante riskiness. Also, while concrete policy choices can in principle be read from banks' financial reports, the discretion banks have in classifying certain assets puts bounds on the exactness of information obtained from these data 25 Write-downs are a summary variable that captures all these facets in a relatively straightforward way.

Nonetheless, write-downs bring with them some limitations which need to be borne in mind. First, write-downs are accounting data. They are not always completely clearly and unambiguously described in company reports 26

Second, and related, firms have discretion of when to announce which write-downs. Also, in October 2008, the SEC allowed banks to switch from mark-to-market accounting to hold-tomaturity accounting. We cover a relatively wide data period, but it is still possible that some write-downs that were announced were not "fair value" losses, or that some losses have not yet been recorded as write-downs ${ }^{27}$ Some studies report that banks use accounting discretion to understate

\footnotetext{
${ }^{25}$ Moreover, investing in one asset class, for example, MBS securities, may have meant simultaneously shifting out of another class; also, MBS investments often were acquired by banks in the process of securitization, so that the choice of banks was, in fact, multi-dimensional.

${ }^{26}$ Naturally, one can debate in each and every case which parts of the announced overall write-downs should be included in the analysis, and it can be difficult to precisely disentangle some of the above categories from each other. We use the sum of all losses associated to the crisis. For a discussion of the challenges and opportunities of accounting in the financial crisis, see Ryan (2008).

${ }^{27}$ For example, write-downs may be overestimated because some firms may have been pushed by government authorities to "come clean." Conversely, write-downs may be underestimated due to the fact that some financial institutions were bailed out just for the bailout funds to flow through indirectly to other banks which could otherwise
} 
the impairment of their real estate related assets (Huizinga and Laeven, 2012). Others find the opposite, namely, that poorly-performing banks overstate unrealized losses ("take a bath") in order to show higher earnings the following year (Fiechter and Meyer, 2009). Yvas (2011) documents that higher corporate governance quality was associated with timelier write-downs in the time period $2007 / 08$. His study takes it as given that the cumulated actual write-downs and those implied by benchmarking devaluations to credit indices are identical per the end of 2008. What is certain is that investors demonstrated a particularly keen interest in write-downs during the financial crisis, which, together with accounting standards (in particular, FAS 157 - Fair Value Measurement which became effective for annual periods beginning on or after November 15, 2007) requiring detailed disclosure, is likely to have reduced opportunities for manipulation.

Other Measures: We use a number of other, established measures of risk-taking. We also use investment in mortgage-backed securities and commercial loans (computed as in Ellul and Yerramilli (2013)), non-interest income (computed as in Ellul and Yerramilli (2013)), and holdings of lowquality real estate assets (computed as in van Bekkum (2016)). Table1 provides details of the data sources. Finally, we run regressions with the distance from default, as provided by Moody's, as the dependent variable. This measure mixes both asset risks and financial risks, and so it is essential to control for a firm's financial position (leverage). We do not interpret this measure as capturing asset risk-taking by management, but use it to analyze whether the market recognizes the riskier profile of a company with strong risk-taking incentives for its management.

\subsubsection{Explanatory Variables}

3.1.2.1 Incentives. We use the incentive measures developed above ${ }^{28}$ In the write-down regressions, we first present a series of specifications using incentives in 2004 as the explanatory variable (because the MBS market grew particularly strongly after 2004), and then present overview results with incentives from each year 2003-2006. In the other regressions we use incentives for each have ended up in deep trouble.

${ }^{28}$ Besides stock and stock options, another determinant of a CEO's risk-taking incentives is his inside debt, e.g., in the form of pension obligations of the firm. van Bekkum (2016) documents the role of this factor in explaining risk-taking choices. In the pre-2006 period, these data are not widely available. 
year.

3.1.2.2 Company Characteristics. We obtain company-specific information from the Compustat Fundamental and Bank Annual databases. As control variables in the main analysis we include proxies for firm size (the logarithm of market capitalization), the ratio of the book value of assets over the market value of assets (as a proxy for the companies potential investment opportunities), and market or book leverage.

3.1.2.3 Corporate Governance Features. We also control for a set of corporate governance variables including (a) CEO Tenure which measures the number of years the CEO has been in office as well as (b) CEO age. (c) We also include log total compensation because Cheng, Hong, and Scheinkman (2015) argue that abnormally high compensation is related to excessive risktaking. (Given that we control for several main determinants of compensation, including total compensation is similar to taking the residual compensation from a regression of compensation on these determinants.) (d) Percentage of independent directors is the fraction of directors on a board classified as independent. These data are from ExecuComp and Riskmetrics, supplemented by hand-collected data where possible. (e) The Governance index is the number of anti-takeover provisions a company has in place (Gompers, Ishii, and Metrick, 2003). A higher value of the Governance index is regarded as less shareholder-friendly governance.

\subsubsection{Endogeneity Concerns}

An association of incentives and risk-taking is subject to endogeneity concerns. We approach the issue of endogeneity by employing a battery of tests, none of which on its own suffices to fully dispel endogeneity concerns, but which collectively ameliorate these concerns.

First, as for reverse causation, in the write-down regressions we consider the relationship between incentives (and other variables) in the years 2003-2006 and outcomes over the years 2007-2008. We do not have information on the decision criteria boards used to allocate incentive packages in a given year. It is conceivable that incentive packages of a given year include options given as a reward 
for undertaking risky deals in earlier years; this would imply an upward bias in the respective estimates. However, this concern is much less likely to apply to incentives in 2004, for example. Incentive packages relevant for that year may, of course, include stock and options given as a reward for other asset risk-taking in prior years, but these potential earlier risky activities do not include the investments that led to write-downs in the financial crisis. Using these earlier years is also attractive because the vast majority of deals related to the subprime and mortgage backed security market originated in the early part of the decade, not in 2006. This is illustrated in Figure4. While subprime mortgages have been used for a long time, the "take-off" of the market occurred around 2003 (e.g., Hässig (2009) for the case of UBS).

\section{FIGURE 4 ABOUT HERE}

Second, asset substitution incentives of managers explicitly take into account leverage. Our regressions, therefore, show the relation between incentives and asset risk-taking for a given level of leverage. One way to interpret this approach is to note that companies are not generally at their optimal financing points (Leary and Roberts, 2005). However, Shue and Townsend (2017) document that exogenous variation in option grants induced by multi-year grant cycles causes managers to increase leverage. An interesting question, therefore, is how incentives to increase leverage depend on the interaction between equity grants and existing debt. This joint consideration is beyond the scope of this paper ${ }^{29}$ The endogeneity of leverage may be less of a concern given that we use market leverage throughout, which fluctuates passively simply because of changes in stock price performance (Welch, 2004). Our results hold more strongly with book leverage.

Third, we control for important firm-level variables, including several governance features that may be correlated both with incentives and risk-taking and are likely to capture important differences between firms. Of course, this still does not rule out the possibility that a positive association between risk-taking incentives and write-downs could arise because of omitted factors that are

\footnotetext{
${ }^{29}$ Future work may jointly model the setting of incentives and the choices of the CEO to both increase firm value return volatility and financial leverage, using an empirical approach as in Coles, Daniel, and Naveen (2006). In principle, not only the level of debt but also the maturity is endogenous (Brockman, Martin, and Unlu, 2010). As explained earlier, in line with Guay (1999) we use identical debt maturities for all financial institutions.
} 
positively correlated with both variables ${ }^{30}$ It is equally possible that we are underestimating the relationship between risk-taking incentives and poor outcomes 31

Fourth, when using dependent variables available in a panel, we can use firm fixed-effects to control for unobserved time-invariant heterogeneity. While again this does not completely eliminate endogeneity concerns, these regressions shed light on the relation of risk-taking incentives and risktaking in the time series.

Fifth, we briefly report on instrumental variables regressions that yield results consistent with a causal effect of incentives on asset risk-taking. However, given the notorious difficulty of finding suitable instruments, we view these results as supplementary checks.

\subsection{Regression Results}

During the credit crisis period, the companies in our sample had on average write-downs of around US $\$ 7.4 \mathrm{bn}$, which implies write-downs of around $5.8 \%$ of their total assets (averaging assets over the years). See Table 2, monetary values are in 2008 dollars. The heterogeneity in asset risk-taking also shows in the standard deviation of write-downs and scaled write-downs. Substantial variation also exists in the other risk-taking measures, such as distance to default and the ratio of interest-income to total income.

Table 4 presents the regression results for write-downs. Column (1) shows that Asset Vega and Asset Delta enter significantly and with the predicted sign 32 By contrast, Equity Vega and Equity Delta are not statistically significantly associated with write-downs in the financial crisis. Note that this result arises even though we control for leverage. Because leverage matters non-linearly

\footnotetext{
${ }^{30}$ For instance, board competence is unobserved. Some may argue that less competent boards are more easily captured by the CEO and may, therefore, grant an excessive number of options to CEOs. Moreover, less competent boards are less able to monitor investments and may provide worse advice to the CEO. These two factors may combine into a cross-sectional positive relationship between risk-taking incentives and write-downs. Or, the least talented CEOs (who choose the worst projects on average) may be inclined to self-select into the firms with the highest risk-taking incentives, to occasionally "hit the jackpot."

${ }^{31}$ For example, if a company has a culture of risk-taking, it may attract risk-seeking individuals and may, thus, need to provide incentives with lower Vega than other firms. At the same time, these companies may, indeed, engage in a lot of risk-taking simply because the manager likes risk.

32 The results with opposite signs for Vega and Delta are similar to what Knopf, Nam, and Thornton (2002) find for corporate hedging activities.
} 
for asset incentives, merely controlling for leverage while continuing to use equity incentives does not in general capture variation in asset incentives.

In a next step, we consider the Asset Incentive Ratio (AIR) and the Equity Incentive Ratio (EIR). As noted in Section 2.5, these quantities can provide useful summary measures of the incentives. Consistent with columns (1) and (2), respectively, columns (3) and (4) show that AIR is highly significantly associated with write-downs, while EIR is not. In fact, when one includes both AIR and EIR, AIR becomes more significant while the coefficient on EIR flips signs (column (5)). Finally, columns (6) and (7) show that the results are robust to adding further control variables ${ }^{33}$

Table 5 explores the time pattern, and it also includes log write-downs in the even-numbered columns, in addition to the scaled write-downs in the odd-numbered columns. For the AIR, all 8 coefficients go in the expected direction, and 6 are highly statistically significant. By contrast, only 2 out of 8 coefficients for EIR go in the expected direction, and 2 are statistically significant but with the wrong sign. In sum, asset incentives outperform equity incentives in explaining the variation in write-downs of US financial institutions in the 2007/08 financial crisis.

One difference between the results for relative asset risk-taking (write-downs scaled by firm size) and absolute asset risk-taking (log write-downs) is that the regressions for the latter generally show greater explanatory power than for the former, in terms of R-squared. Indeed, only asset incentives offer explanatory power for write-downs scaled by assets; by contrast, there is no size effect in relative asset risk-taking, for example.

\section{TABLES 4 and 5 ABOUT HERE}

We find no robust association of any of the governance characteristics with write-downs, controlling for incentives to take asset risk; this is illustrated in column (7) of Table 4 . That we detect no significant relationship between director independence and write-downs may be the result of several countervailing factors. On the one hand, boards acting more strongly on behalf of shareholders may

\footnotetext{
${ }^{33}$ It is conceivable that taking a ratio of Vega and Delta does worse for equity incentives than for asset incentives. Therefore, the results for Vega and Delta individually are still relevant. We have also experimented with higher-order terms for Vega and Delta, but this does not lead to equity incentives significantly explaining write-downs.
} 
have pushed CEOs to engage in more asset risk-taking (thus implying a positive relationship) ${ }^{34}$ On the other hand, such boards may also have been more prudent in avoiding the worst investments. Moreover, board independence need not capture competence (Fernandes and Fich, 2016).

Next, we turn to a number of specific measures of risk-taking by financial institutions. Panel A of Table 6 shows results for Vega and Delta separately for baseline specifications. Together, these results imply that investments in MBS and commercial loans, investments in low-quality real estate, and non-interest income activities were more likely to be conducted by financial institutions where the CEO had pronounced incentives to take asset risk. Equity incentives explain variation in non-interest income, but do not explain investments in MBS and in low-quality real estate. These results also hold when using the Incentive Ratios, as seen in columns (1) to (3) of Panel B. The results are somewhat weaker when including additional firm and governance characteristics as well as firm fixed effects, in columns (4) to (6). In this most challenging specification, neither of the two incentives appears to explain within-firm differences in non-interest income activities; asset incentives are associated with investments in MBS at just below conventional significance, and they significantly explain investments in low-quality real estate.

\section{TABLE 6 ABOUT HERE}

As a final dependent variable, we consider distance to default (DD), again using panel regressions. Distance to default captures the market's assessment of the riskiness of the financial institution. Column (1) of Table 7 shows that Asset Volatility Vega is negatively associated with DD, while Asset Delta is positively associated with DD. By contrast, the equity incentive measures do not explain variation in DD; see column (2). Again, this result also holds when combining the measures into the Asset Incentive Ratio and Equity Incentive Ratio, respectively; see columns (3) and (4). Importantly, this continues to be the case when including firm fixed effects, from columns (5) onwards. These results suggest that the market recognized that asset incentives played a role

\footnotetext{
${ }^{34}$ It is also possible that more independent boards forced executives to disclose write-downs earlier or higher. This argument only holds if one posits that despite the strict accounting regime and the eagerness of investors to monitor developments at financial institutions, some banks were able to manipulate the total amount of write-downs in the six quarters considered here.
} 
for the risk position of financial institutions.

\section{TABLE 7 ABOUT HERE}

Finally, we consider two instrumental variables for incentives: (1) Higher equity volatilities (measured over 5 years prior to the year when we measure the incentives) are positively correlated with current incentives because they indicate that it was relatively cheap to grant CEOs stock options, and the historical volatility can arguably be excluded from regressions explaining asset risk-taking just before the crisis ${ }^{35}$ (2) Longer CEO tenure is negatively correlated with current incentives because greater CEO power may mute a board's ability to implement strong incentives. As argued by van Bekkum (2016), there exists considerable ambiguity as to how personal characteristics, in particular risk aversion, change with age and tenure, so it is far from clear whether tenure would have a direct effect on risk-taking. With these instruments we obtain results, in columns (1) to (3) of Table 8, supportive of a significant, positive causal impact of the Asset Incentive Ratio on risk-taking ${ }^{36}$ Finally, columns (4) to (6) jointly instrument the Asset Incentive Ratio and the Equity Incentive Ratio, providing further suggestive evidence of such a causal impact. However, the reliability of 2SLS may be limited with this small sample size, so we regard these results as supplementary evidence.

\section{TABLE 8 ABOUT HERE}

Overall, the findings reported in this section broadly provide support for Hypotheses 1, 2 and 3, confirming the idea of a link between asset risk-taking and incentives to take asset risk. By contrast, we do not find a significant relationship between equity incentives and asset risk-taking. Of course, given that the Asset Incentive Ratio and the Equity Incentive Ratio are correlated, we do find

\footnotetext{
${ }^{35}$ Indeed, studies aiming to explain risk-taking do not generally use historical volatility as an explanatory variable because there is no reason to expect a direct effect.

${ }^{36}$ As shown in Table 8, the first-stage F-statistic is, for two out of three cases, above the critical value of 11.59 for two instruments suggested by Stock, Wright, and Yogo (2002), ameliorating weak instruments concerns. The Hansen-Sargan J statistic yields a p-value of above 0.1, implying that, conditional on one instrument fulfilling the exclusion restriction, the other instrument is also likely to be valid. A Hausman test (in the two instruments version) has a p-value of around 0.1, suggesting that the data do not actually reject the use of OLS in favor of 2SLS (the point estimates are not very different).
} 
some relationship between the Equity Incentive Ratio and asset risk-taking, too, but the relation is overall much weaker. Thus, our analysis documents that, in order to explain asset risk-taking, it can be important to use asset incentives instead of equity incentives.

\section{Concluding Remarks}

This paper offers one of the first investigations of the quantitative importance of managerial incentives to take asset risk. It is motivated by the observation that, while the notion that asset risk-taking incentives depend on leverage has been a cornerstone of corporate finance since Jensen and Meckling (1976), the measures of equity incentives typically employed in research do not explicitly incorporate this idea. The asset incentives we calculate, instead, reflect the intuition that variation of leverage between companies needs to be taken into account when trying to understand managerial incentives to take risk. Each incentive measure should be used in the context where it is appropriate.

We show that the conceptual idea that asset incentives differ from equity incentives is also relevant quantitatively. We document three main results. First, incentives to take asset risk can be large compared to incentives to increase the value of assets; this provides a contrast to the fact that incentives to take equity risk are usually small compared to incentives to increase the stock price. Second, stock-holdings can also induce substantial asset risk-taking incentives; thus, the proposal, often heard in practice, to compensate CEOs mostly with stock rather than stock options, in order to rein in risk-taking incentives does not apply so cleanly anymore. Third, in our empirical application in the context of the financial crisis, asset incentives possess considerable explanatory power for asset risk-taking; using equity incentives, one would instead erroneously conclude that managerial incentives were unrelated to the asset risks that financial institutions took in the years before the financial crisis 2007/08.

These results may prove helpful for future studies on incentives and risk-taking and may aid boards and policy-makers in evaluating the incentives conveyed by equity-based compensation. 


\section{References}

Adams, René, 2012, Governance and the financial crisis, International Review of Finance 12, 7-38.

Anderson, Joshua D., and John E. Core, 2016, Managerial incentives to increase risk provided by debt, stock, and options, Working paper.

Bebchuk, Lucian A., Alma Cohen, and Holger Spamann, 2010, The wages of failure: Executive compensation at Bear Stearns and Lehman 2000-2008, Yale Journal on Regulation 27, 257-282.

Bebchuk, Lucian A., and Holger Spamann, 2010, Regulating bankers' pay, Georgetown Law Journal 102, 957-993.

Black, Fischer, and Myron Scholes, 1973, The pricing of options and corporate liabilities, Journal of Political Economy 81, 637-654.

Board of Governors of the Federal Reserve System, 2011, Incentive Compensation Practices: A Report on the Horizontal Review of Practices at Large Banking Organizations, October 2011.

Bolton, Patrick, Hamid Mehran, and Joel Shapiro, 2015, Executive compensation and risk taking, Review of Finance 19, 2139-2181.

Brockman, Paul, Xiumin Martin, and Emre Unlu, 2010, Executive compensation and the maturity structure of corporate debt, The Journal of Finance 65, 1123-1161.

Carpenter, Jennifer N., 2000, Does option compensation increase managerial risk appetite?, The Journal of Finance 55, 2311-2331.

Cheng, Ing-Haw, Harrison Hong, and Jose Scheinkman, 2015, Yesterday's heroes: Compensation and creative risk-taking, The Journal of Finance 70, 839-879.

Coles, J., N. Daniel, and Lalitha Naveen, 2006, Managerial incentives and risk-taking, Journal of Financial Economics 79, 431-468.

Core, John E., and Wayne R. Guay, 2002, Estimating the value of employee stock option portfolios and their sensitivities to price and volatility, Journal of Accounting Research 40, 613-629.

DeYoung, Robert, Emma Y. Peng, and Meng Yan, 2013, Executive compensation and business policy choices at U.S. commercial banks, Journal of Financial and Quantitative Analysis 48, 165-196.

Dittmann, Ingolf, Ko-Chia Yu, and Dan Zhang, 2017, How important are risk-taking incentives in executive compensation?, Review of Finance 21, 1805-1846.

Ellul, Andrew, and Vijay Yerramilli, 2013, Stronger risk controls, lower risk: Evidence from u.s. bank holding companies, The Journal of Finance 68, 1757-1804.

Erkens, David H., Mingyi Hung, and Pedro Matos, 2012, Corporate governance in the 2007-2008 financial crisis: Evidence from financial institutions worldwide, Journal of Corporate Finance 18, $389-411$.

Fahlenbrach, Rüdiger, and René Stulz, 2011, Bank CEO incentives and the credit crisis, Journal of Financial Economics 99, 11-26. 
Faulkender, Michael, Dalida Kadyrzhanova, N. Prabhala, and Lemma Senbet, 2010, Executive compensation: An overview of research on corporate practices and proposed reforms, Journal of Applied Corporate Finance 22, 107-118.

Fernandes, Nuno, and Eliezer M. Fich, 2016, Are outside directors with greater board tenure valuable? Evidence from the last credit crisis, Working Paper.

Fiechter, Peter, and Conrad Meyer, 2009, Big bath accounting using fair value measurement discretion during the financial crisis, Working Paper.

Geske, Robert, 1979, The valuation of compound options, Journal of Financial Economics 7, 63-81.

Gompers, Paul A., Joy L. Ishii, and Andrew Metrick, 2003, Corporate governance and equity prices, Quarterly Journal of Economics 118, 107-156.

Graham, John R., Campbell R. Harvey, and Manju Puri, 2013, Managerial attitudes and corporate actions, Journal of Financial Economics 109, 103-121.

Gropp, Reint, and Florian Heider, 2010, The determinants of bank capital structure, Review of Finance 14, 257-282.

Guay, Wayne, 1999, The sensitivity of CEO wealth to equity risk: An analysis of the magnitude and determinants, Journal of Financial Economics 53, 43-71.

Hässig, Lukas, 2009, Der UBS-Crash (Hoffmann und Campe: Hamburg).

Haugen, Robert A., and Lemma W. Senbet, 1981, Resolving the agency problem of external capital through options, The Journal of Finance 36, 629-647.

Hayes, Rachel M., Michael Lemmon, and Mingming Qiu, 2012, Stock options and managerial incentives for risk-taking: Evidence from FAS 123R, Journal of Financial Economics 105, 174190.

Huizinga, Harry, and Luc Laeven, 2012, Bank valuation and accounting discretion during a financial crisis, Journal of Financial Economics 106, 614-634.

Ingersoll, Jonathan, 2006, The subjective and objective evaluation of incentive stock options, Journal of Business 79, 453-487.

Jensen, Michael, and William H. Meckling, 1976, Theory of the firm: Managerial behavior, agency costs, and ownership structure, Journal of Financial Economics 3, 305-360.

John, Kose, Hamid Mehran, and Yiming Qian, 2010, Outside monitoring and CEO compensation in the banking industry, Journal of Corporate Finance 16, 383-399.

John, Kose, Anthony Saunders, and Lemma W. Senbet, 2000, A theory of bank regulation and management compensation, Review of Financial Studies 13, 95-112.

John, Teresa A., and Kose John, 1993, Top-management compensation and capital structure, The Journal of Finance 48, 949-974.

Knopf, John D., Jouahn Nam, and John H. Thornton, 2002, The volatility and price sensitivities of managerial stock option portfolios and corporate hedging, The Journal of Finance 57, 801-813.

Laeven, Luc, and Ross Levine, 2009, Bank governance, regulation and risk taking, Journal of Financial Economics 93, 259-275. 
Lambert, Richard A., David F. Larcker, and Robert E. Verrecchia, 1991, Portfolio considerations in valuing executive compensation, Journal of Accounting Research 29, 129-149.

Leary, Mark T., and Michael R. Roberts, 2005, Do firms rebalance their capital structures?, The Journal of Finance 60, 2575-2619.

Merton, Robert, 1974, On the pricing of corporate debt: The risk structure of interest rates, The Journal of Finance 3, 449-470.

Murphy, Kevin J., 2011, Pay, politics and the financial crisis, in Alan Blinder, Andrew Lo, and Robert Solow, ed.: Economic lessons from the financial crisis (Russell Sage Foundation).

Nagel, Stefan, and Amiyatosh Purnanandam, 2015, Bank risk dynamics and distance to default, Working paper.

PricewaterhouseCoopers, 2008, Reward: A new paradigm?, PwC.

Ross, Stephen A., 2004, Compensation, incentives, and the duality of risk aversion and riskiness, The Journal of Finance 59, 207-225.

Ryan, Stephen G., 2008, Accounting in and for the subprime crisis, Accounting Review 83, 16051638.

Sanders, WM. Gerard, and Donald C. Hambrick, 2007, Swinging for the fences: The effects of CEO stock options on company risk taking and performance, Academy of Management Journal 50, $1055-1078$.

Saunders, Anthony, Elizabeth Strock, and Nickolaos G. Travlos, 1990, Ownership structure, deregulation, and bank risk taking, The Journal of Finance 45, 643-654.

Sheehan, Richard G., 2004, Valuing core deposits, Working paper, Department of Finance, University of Notre Dame.

Shue, Kelly, and Richard Townsend, 2017, How do quasi-random option grants affect CEO risktaking?, The Journal of Finance 72, 2551-2588.

Stock, James H., Jonathan H. Wright, and Motohiro Yogo, 2002, A survey of weak instruments and weak identification in generalized method of moments, Journal of Business and Economics Statistics 20, 518-529.

van Bekkum, Sjoerd, 2016, Inside debt and bank risk, Journal of Financial and Quantitative Analysis $51,359-385$.

Welch, Ivo, 2004, Capital structure and stock returns, Journal of Political Economy 112, 106-131.

Yvas, Dushyantkumar, 2011, The timeliness of write-downs by U.S. financial institutions during the financial crisis of 2007-2008, Journal of Accounting Research 49, 823-860. 


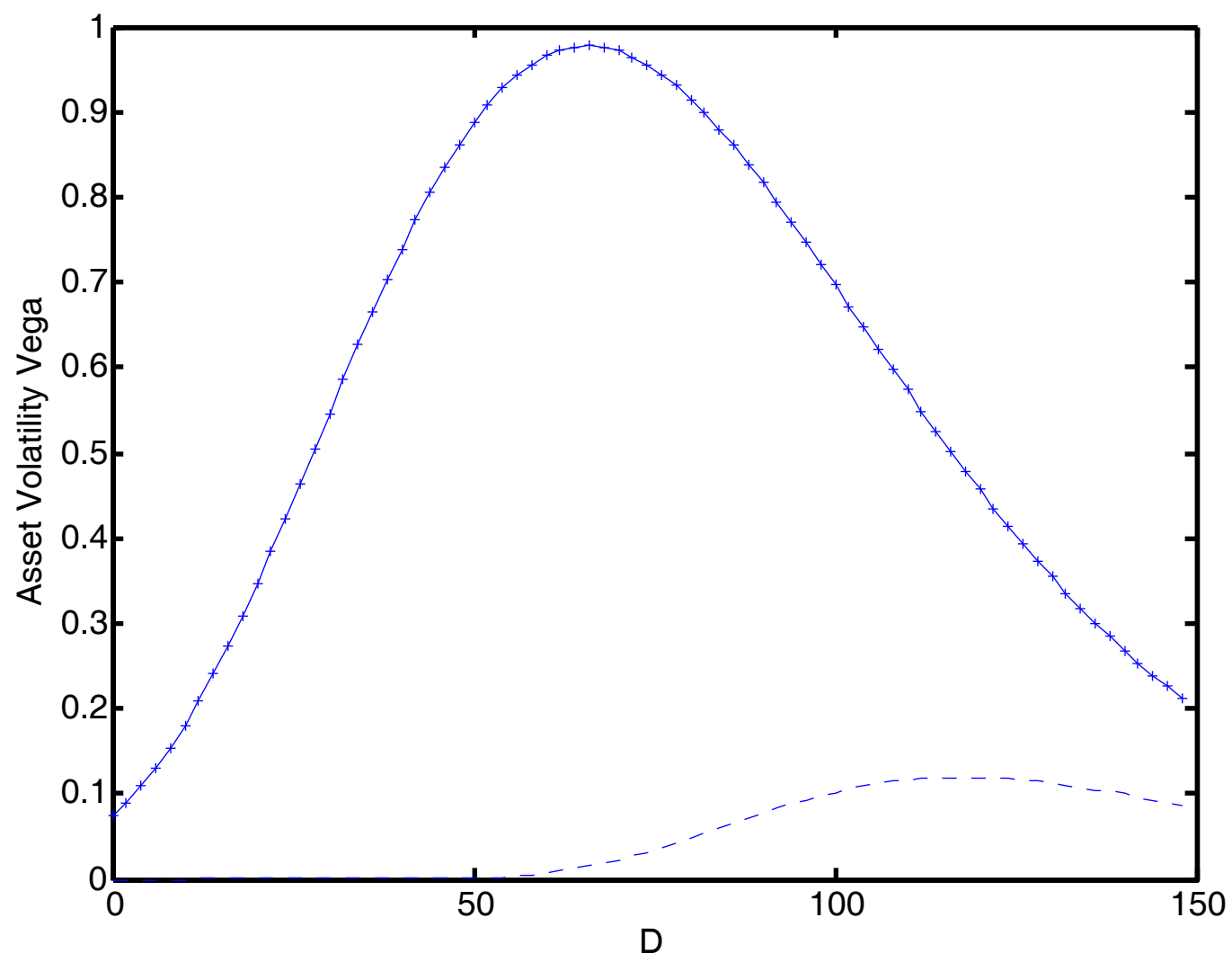

Figure 1

Asset Volatility Vega of a single stock option as a function of debt.

This graph plots Asset Volatility Vega of a single stock option for varying levels of the face value of debt, $D$, computed using three different approaches: The Geske (1979) approach (dotted line), our analytical result derived in Proposition 1 ("+") and the difference approximation (solid line). See Section 2.2 for details. The parameters are $V=100, K=50$, $r=0.04, T_{D}=10, T_{C C}=6$ and $\sigma_{V}=0.10 . \Delta=10^{-11}$ is used to calculate the difference approximation. 


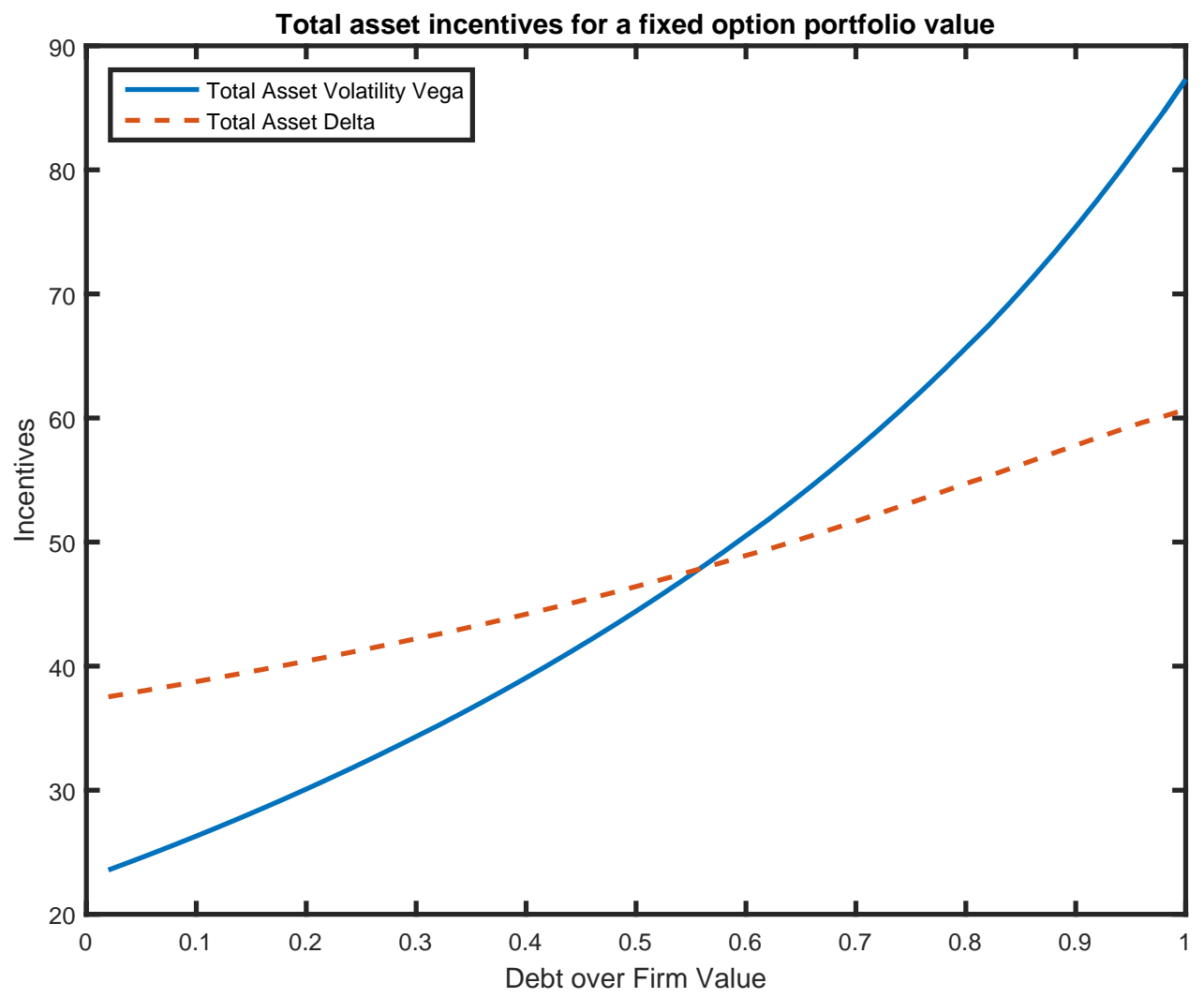

Figure 2

Asset Volatility Vega as a function of debt.

This graph plots Asset Volatility Vega and Asset Delta of a portfolio of stock options for varying levels of leverage, $D / V$, keeping the Black-Scholes value of the overall option package constant at 1000 . The stock price is implied by the Merton (1974) model, and the options are given at-the-money. The remaining parameters are $V=100, r=0.04$, $T_{D}=10, T_{C C}=6, \sigma_{V}=0.10$ and $\sigma_{D}=0.04$. 


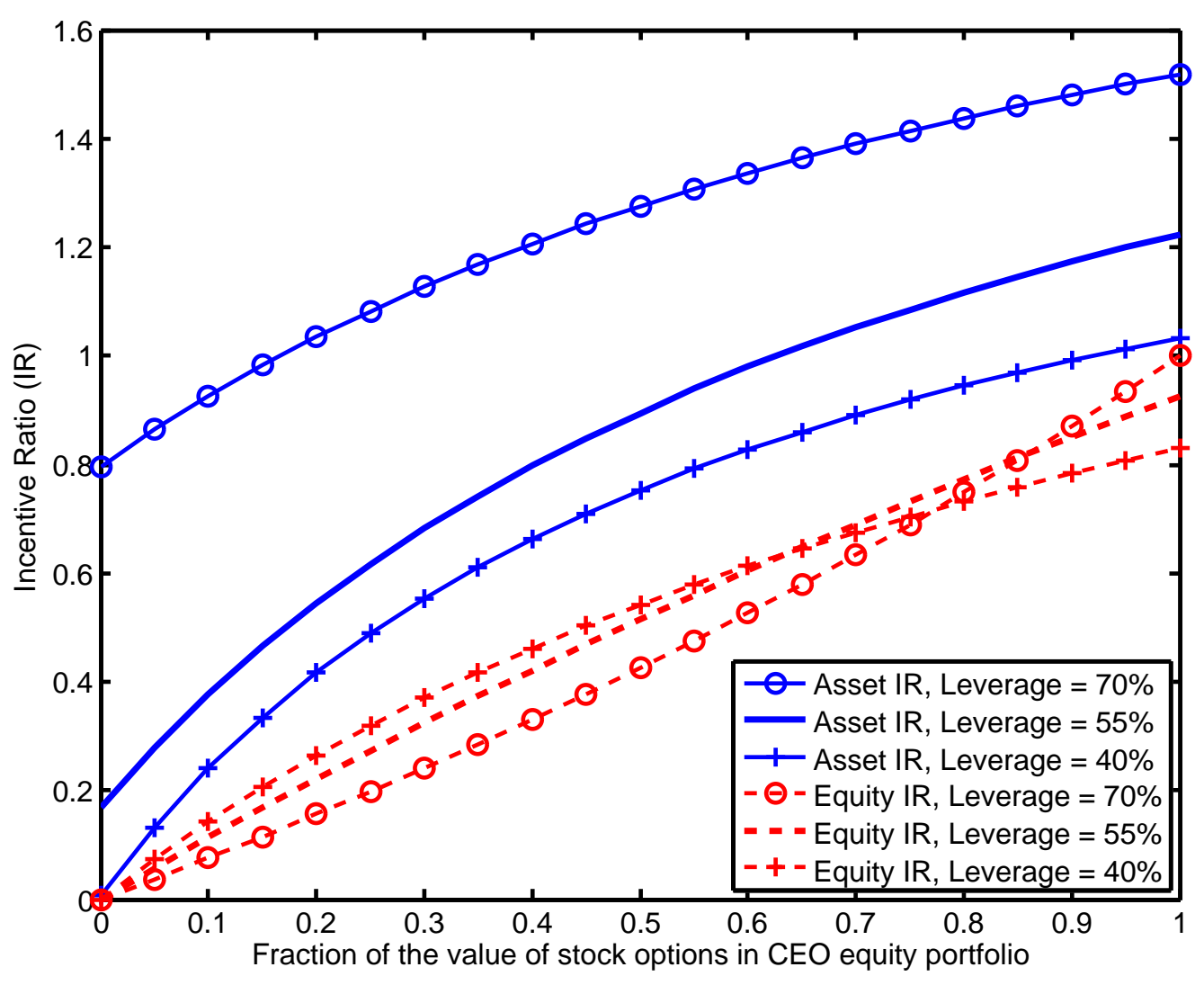

Figure 3

Incentive ratios.

This graph plots the two incentive ratios (IR), the Asset Incentive Ratio (solid lines) and the Equity Incentive Ratio (dotted lines), for different combinations of stocks and stock options, for a given value of the total equitybased compensation package. For the Asset Incentive Ratio, sensitivities of stocks and stock options are calculated according to the model described in Section 2.2, using in particular the Merton (1974) model and the compound option framework for stock options (Geske, 1979), but using our analytical result for Asset Volatility Vega of a stock option (see Proposition 1). The parameters for the Asset Incentive Ratio are $V=100, r=0.04, T_{D}=10, T_{C C}=6$, $\sigma_{V}=0.04$ and $\sigma_{V}=0.10$. For the Equity Incentive Ratio, sensitivities are calculated as described in Section 2.3 . using the Black-Scholes model, also using 6 years as the stock option maturity. The face value of debt is varied to capture different degrees of leverage. Variation in leverage implies variations in the value of equity according to the Merton (1974) model. For both incentive ratios, we choose the strike price for the stock options to be equal to the stock price implied from the Merton (1974) model at each point, i.e., stock options are granted at-the-money. The stock return volatility is numerically determined through the portfolio relationship described in Appendix C 


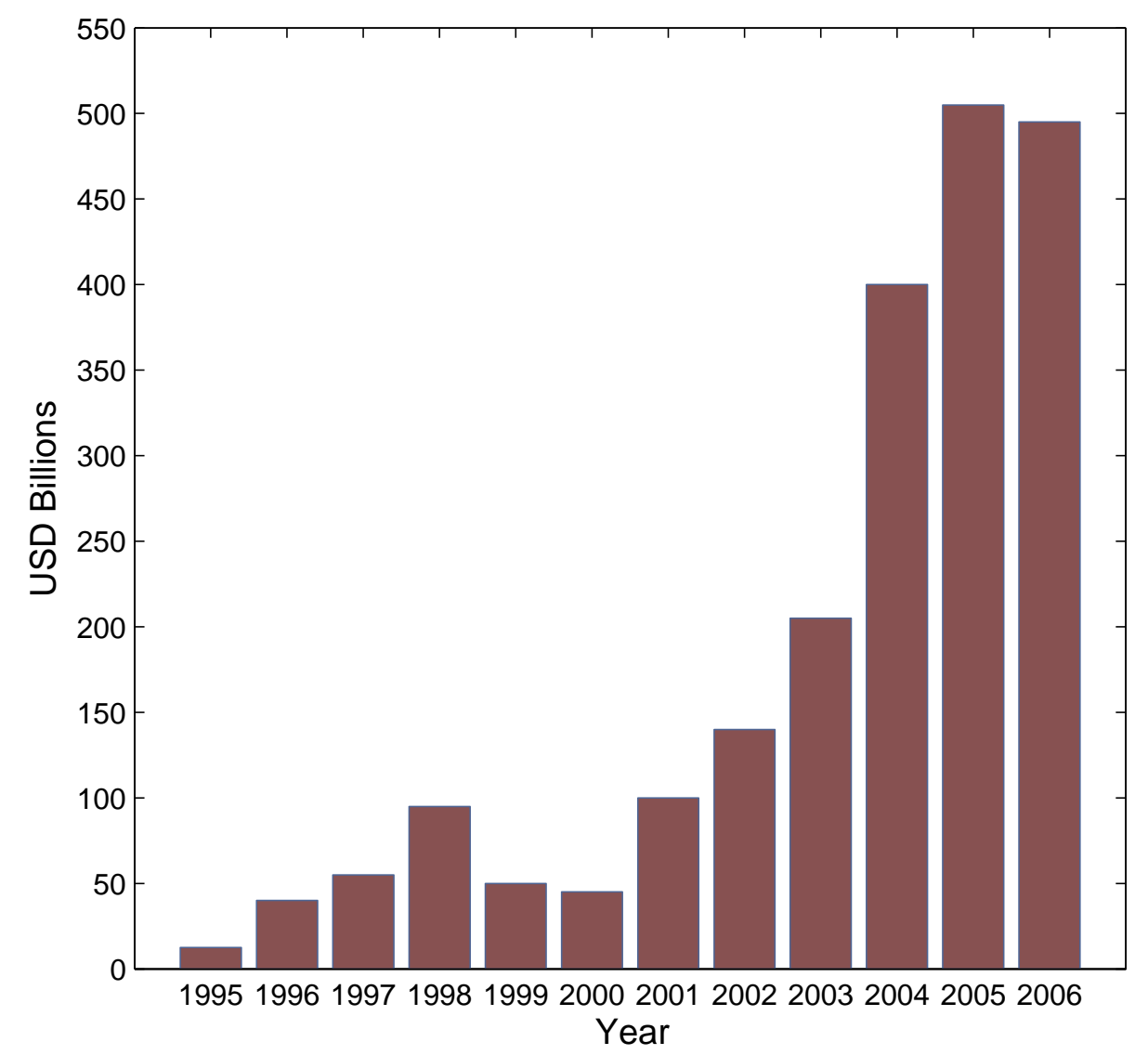

Figure 4

The development in subprime mortgage securitization over the years 1995-2006. Source: www.subprimer.org. 


\section{Table 1}

Variables description.

\begin{tabular}{|c|c|}
\hline Write-downs (USD mill.) & $\begin{array}{l}\text { The losses incurred by the financial institutions during the } \\
\text { financial crisis period } 2007 \mathrm{Q} 3-2008 \mathrm{Q} 4 \text {, collected from } \\
\text { Bloomberg, 10-K, and 10-Q filings. For details, see Section 3.1.1 }\end{array}$ \\
\hline Write-downs scaled by total assets & Write-downs divided by a company's total assets. \\
\hline $\begin{array}{l}\text { Investment in MBS } \\
\text { and commercial loans }\end{array}$ & $\begin{array}{l}\text { Year-on-year change in the sum of two ratios: } \\
\text { the ratio of commercial and industrial loans (BHDM1766 } \\
\text { in the FR Y-9C reports) to assets, as in Ellul and Yerramilli }(2013) \text {, } \\
\text { plus the ratio of MBS investments to total assets, where MiBS } \\
\text { is the sum of the following variables from the FR Y-9C reports: } \\
\text { BHCK1709, BHCK1733. BHCK } 1713 \text {, BHCK1736 and BHCK3536, } \\
\text { as in Ellul and Yerramilli (2013) }\end{array}$ \\
\hline Low-quality real estate & $\begin{array}{l}\text { The ratio of nonperforming assets on real estate (NPAORE in Compustat) } \\
\text { relative to total assets, as in van Bekkum }(2016)\end{array}$ \\
\hline Non-interest income & $\begin{array}{l}\text { The ratio of non-interest income to the sum of interest } \\
\text { income and non-interest income, as in Ellul and Yerramilli (2013), } \\
\text { computed from FR-Y-9C reports. }\end{array}$ \\
\hline Distance to default & Moody's Distance to Default measure. \\
\hline
\end{tabular}

CEO compensation

Equity Volatility Vega (1000 USD)

The dollar change in the CEO's wealth for a 0.01 change in the standard deviation of returns.

Equity Delta (1000 USD)

The dollar change in the CEO's wealth with respect

to a one percent change in the underlying stock price.

Equity Incentive Ratio

Equity Volatility Vega divided by Equity Delta

Asset Volatility Vega (1000 USD)

The dollar change in the CEO's wealth for a 0.01 change in the standard deviation of firm value returns.

Asset Delta (1000 USD)

The dollar change in the CEO's wealth with respect to a one percent change in the underlying firm value.

Asset Incentive Ratio

Asset Volatility Vega divided by Asset Delta

Ln(total compensation)

The natural logarithm of CEO total compensation

Firm Characteristics

\begin{tabular}{|c|c|}
\hline Market Cap. (USD mill.) & $\begin{array}{l}\text { The number of shares times end-of-year } \\
\text { stock price plus the book value of liabilities }\end{array}$ \\
\hline Total assets (USD mill.) & Total assets on the company's balance sheet. \\
\hline Book-to-Market ratio & Book value of assets over market value of assets. \\
\hline Book leverage & 1 - (book value of equity / book value of assets) \\
\hline Market leverage & 1 - (market value of equity / market value of the financial institution) \\
\hline \multicolumn{2}{|l|}{ Governance } \\
\hline Percentage independent directors $(\%)$ & The fraction of directors on a board classified as independent. \\
\hline CEO tenure & The number of years the CEO has been in office. \\
\hline Governance index & $\begin{array}{l}\text { The number of anti-takeover provisions a company } \\
\text { has in place (Gompers, Ishii, Metrick 2003). }\end{array}$ \\
\hline
\end{tabular}




\section{Table 2}

\section{Summary statistics I.}

Summary statistics of dependent variables, risk-taking incentives, and selected explanatory variables averaged over the years 2003-2006. The variables are described in Table 1. All variables are winsorized at the 1st and 99th percentiles on an annual basis. The Asset Incentive Ratio and the Equity Incentive Ratio represent Asset Volatility Vega divided by Asset Delta and Equity Volatility Vega divided by Equity Delta, respectively. For details on parameter choices, see the text. The term "q" denotes the quantile, i.e., 10q refers to the 10th quantile in the empirical distribution of the particular variable. All monetary values are expressed in 2008 dollars.

\begin{tabular}{|c|c|c|c|c|c|c|c|}
\hline & Mean & Std. Dev. & $10 q$ & $25 q$ & median & $75 q$ & $90 q$ \\
\hline \multicolumn{8}{|l|}{ Dependent variables } \\
\hline $\begin{array}{l}\text { Write-downs (USD mill.) } \\
\text { Write-downs scaled by total assets } \\
\text { Investment in MBS and comm. loans } \\
\text { Low-quality real estate } \\
\text { Non-interest income } \\
\text { Distance to default }\end{array}$ & $\begin{array}{r}7338.7 \\
0.058 \\
0.002 \\
0.041 \\
0.244 \\
3.163\end{array}$ & $\begin{array}{r}18253.5 \\
0.082 \\
0.026 \\
0.055 \\
0.145 \\
0.356 \\
\end{array}$ & $\begin{array}{r}18.0 \\
0.003 \\
-0.024 \\
0.000 \\
0.075 \\
2.785\end{array}$ & $\begin{array}{r}119.4 \\
0.013 \\
-0.011 \\
0.004 \\
0.139 \\
3.016\end{array}$ & $\begin{array}{r}552.8 \\
0.030 \\
-0.001 \\
0.020 \\
0.222 \\
3.183 \\
\end{array}$ & $\begin{array}{r}3259.7 \\
0.070 \\
0.010 \\
0.057 \\
0.311 \\
3.362 \\
\end{array}$ & $\begin{array}{r}23459.7 \\
0.151 \\
0.026 \\
0.099 \\
0.450 \\
3.630 \\
\end{array}$ \\
\hline \multicolumn{8}{|l|}{ CEO incentives } \\
\hline $\begin{array}{l}\text { Equity Volatility Vega (USD 1000) } \\
\text { Equity Delta (USD 1000) } \\
\text { Equity Incentive Ratio } \\
\text { Asset Volatility Vega (USD 1000) } \\
\text { AVV due to stocks (USD 1000) } \\
\text { AVV due to options (USD 1000) } \\
\text { Asset Delta (USD 1000) } \\
\text { AD due to stocks (USD 1000) } \\
\text { AD due to options (USD 1000) } \\
\text { Asset Incentive Ratio }\end{array}$ & $\begin{array}{r}251.4 \\
1004.1 \\
0.33 \\
3128.8 \\
1338.9 \\
1695.8 \\
5692.5 \\
3077.9 \\
2543.6 \\
0.48\end{array}$ & $\begin{array}{r}388.8 \\
1577.6 \\
0.29 \\
7180.5 \\
4741.6 \\
3146.9 \\
11463.6 \\
9090.7 \\
4146.2 \\
0.32\end{array}$ & $\begin{array}{r}4.4 \\
38.7 \\
0.02 \\
34.1 \\
1.5 \\
12.5 \\
150.0 \\
34.1 \\
47.4 \\
0.08\end{array}$ & $\begin{array}{r}19.8 \\
121.2 \\
0.09 \\
142.9 \\
14.2 \\
85.5 \\
487.9 \\
173.1 \\
182.0 \\
0.22\end{array}$ & $\begin{array}{r}80.7 \\
443.9 \\
0.27 \\
712.1 \\
89.8 \\
400.6 \\
1873.4 \\
721.0 \\
823.2 \\
0.45\end{array}$ & $\begin{array}{r}309.6 \\
1080.8 \\
0.50 \\
2540.9 \\
523.6 \\
1712.0 \\
5748.0 \\
2246.6 \\
2814.4 \\
0.67\end{array}$ & $\begin{array}{r}786.9 \\
2642.9 \\
0.72 \\
8473.4 \\
1944.6 \\
4588.2 \\
14402.6 \\
6449.3 \\
8187.9 \\
0.91\end{array}$ \\
\hline \multicolumn{8}{|l|}{ Firm characteristics } \\
\hline $\begin{array}{l}\text { Market cap (USD mill.) } \\
\text { Total assets (USD mill.) } \\
\text { Book-to-market ratio } \\
\text { Book leverage } \\
\text { Market leverage }\end{array}$ & $\begin{array}{r}13921.8 \\
100520.7 \\
0.50 \\
0.89 \\
0.79\end{array}$ & $\begin{array}{r}31143.2 \\
253011.0 \\
0.19 \\
0.09 \\
0.13\end{array}$ & $\begin{array}{r}598.8 \\
2214.7 \\
0.27 \\
0.84 \\
0.70\end{array}$ & $\begin{array}{r}970.8 \\
4747.4 \\
0.37 \\
0.89 \\
0.78\end{array}$ & $\begin{array}{r}2205.9 \\
10885.4 \\
0.49 \\
0.91 \\
0.82\end{array}$ & $\begin{array}{r}10402.5 \\
52592.0 \\
0.60 \\
0.93 \\
0.86\end{array}$ & $\begin{array}{r}39293.2 \\
255949.9 \\
0.73 \\
0.94 \\
0.89\end{array}$ \\
\hline \multicolumn{8}{|l|}{ Governance } \\
\hline $\begin{array}{l}\text { Percentage independent directors } \\
\text { CEO tenure } \\
\text { Governance index }\end{array}$ & $\begin{array}{r}61.9 \\
5.8 \\
8.5\end{array}$ & $\begin{array}{r}27.9 \\
5.3 \\
4.3\end{array}$ & $\begin{array}{l}0.0 \\
0.0 \\
0.0\end{array}$ & $\begin{array}{r}55.6 \\
2.0 \\
6.0\end{array}$ & $\begin{array}{r}71.4 \\
5.0 \\
9.0\end{array}$ & $\begin{array}{r}80.0 \\
9.0 \\
12.0\end{array}$ & $\begin{array}{l}86.7 \\
14.0 \\
13.0\end{array}$ \\
\hline
\end{tabular}




\section{Table 3}

\section{Summary statistics II}

Summary statistics of Asset Volatility Vega (AVV) and Asset Delta (AD) divided into incentives coming from stock holdings and stock options, respectively, across the years 2003-2006 for all financial institutions in our sample. The Asset Incentive Ratio (AIR) and the Equity Incentive Ratio (EIR) represent Asset Volatility Vega divided by Asset Delta and Equity Volatility Vega divided by Equity Delta, respectively, combining stocks and stock options. The variables are winsorized at the 1st and 99th percentiles on an annual basis. The term " $\mathrm{q}$ " denotes the quantile, i.e., 10q refers to the 10th quantile in the empirical distribution of the respective variable. All monetary values are denominated in USD 1000 and expressed in year 2008 dollars.

\begin{tabular}{|c|c|c|c|c|c|c|c|c|c|}
\hline Year & Incentives & Source & Mean & Std. Dev. & $10 q$ & $25 q$ & Median & $75 q$ & $90 q$ \\
\hline \multirow[t]{6}{*}{2003} & AVV & due to stocks & 1610.6 & 4789.4 & 7.9 & 33.3 & 153.7 & 697.2 & 3300.8 \\
\hline & AVV & due to options & 2468.1 & 3869.4 & 43.0 & 196.1 & 953.2 & 2804.4 & 7985.5 \\
\hline & $\mathrm{AD}$ & due to stocks & 2830.6 & 6286.3 & 61.1 & 226.7 & 769.4 & 2148.5 & 5864.3 \\
\hline & $\mathrm{AD}$ & due to options & 2929.6 & 4017.5 & 109.0 & 305.4 & 1517.3 & 3653.0 & 8621.1 \\
\hline & AIR & both & 0.62 & 0.35 & 0.20 & 0.33 & 0.61 & 0.88 & 1.08 \\
\hline & EIR & both & 0.37 & 0.25 & 0.05 & 0.16 & 0.36 & 0.52 & 0.77 \\
\hline \multirow[t]{6}{*}{2004} & AVV & due to stocks & 2004.8 & 6774.4 & 7.3 & 24.4 & 132.8 & 685.1 & 2561.8 \\
\hline & AVV & due to options & 2264.1 & 3649.8 & 48.7 & 180.4 & 856.2 & 2290.9 & 8664.4 \\
\hline & $\mathrm{AD}$ & due to stocks & 2957.6 & 6356.0 & 91.5 & 237.8 & 848.3 & 2468.1 & 6682.0 \\
\hline & $\mathrm{AD}$ & due to options & 3128.2 & 4579.5 & 113.2 & 351.7 & 1452.5 & 3685.5 & 8871.8 \\
\hline & AIR & both & 0.54 & 0.30 & 0.14 & 0.32 & 0.52 & 0.74 & 0.96 \\
\hline & EIR & both & 0.36 & 0.24 & 0.05 & 0.14 & 0.31 & 0.57 & 0.70 \\
\hline \multirow[t]{6}{*}{2005} & AVV & due to stocks & 1917.4 & 6082.5 & 5.9 & 26.8 & 128.9 & 977.1 & 2228.5 \\
\hline & AVV & due to options & 2210.2 & 3534.5 & 85.5 & 184.8 & 844.7 & 2425.5 & 7884.4 \\
\hline & $\mathrm{AD}$ & due to stocks & 4290.3 & 12241.8 & 86.3 & 370.2 & 834.1 & 2411.4 & 6297.8 \\
\hline & $\mathrm{AD}$ & due to options & 3386.8 & 4658.3 & 118.0 & 346.0 & 1497.1 & 3752.9 & 10863.3 \\
\hline & AIR & both & 0.50 & 0.30 & 0.12 & 0.28 & 0.50 & 0.66 & 0.90 \\
\hline & EIR & both & 0.39 & 0.30 & 0.04 & 0.13 & 0.33 & 0.59 & 0.82 \\
\hline \multirow[t]{6}{*}{2006} & AVV & due to stocks & 1149.6 & 3536.0 & 2.2 & 9.2 & 75.2 & 428.6 & 1938.9 \\
\hline & AVV & due to options & 1493.3 & 2626.3 & 24.4 & 77.4 & 392.1 & 1703.3 & 3805.2 \\
\hline & $\mathrm{AD}$ & due to stocks & 4161.3 & 13191.7 & 86.6 & 219.4 & 792.5 & 2497.2 & 7519.0 \\
\hline & $\mathrm{AD}$ & due to options & 2924.9 & 4731.7 & 69.2 & 226.9 & 965.5 & 3208.6 & 10398.5 \\
\hline & AIR & both & 0.39 & 0.29 & 0.07 & 0.17 & 0.37 & 0.49 & 0.67 \\
\hline & EIR & both & 0.29 & 0.24 & 0.03 & 0.09 & 0.23 & 0.42 & 0.60 \\
\hline
\end{tabular}




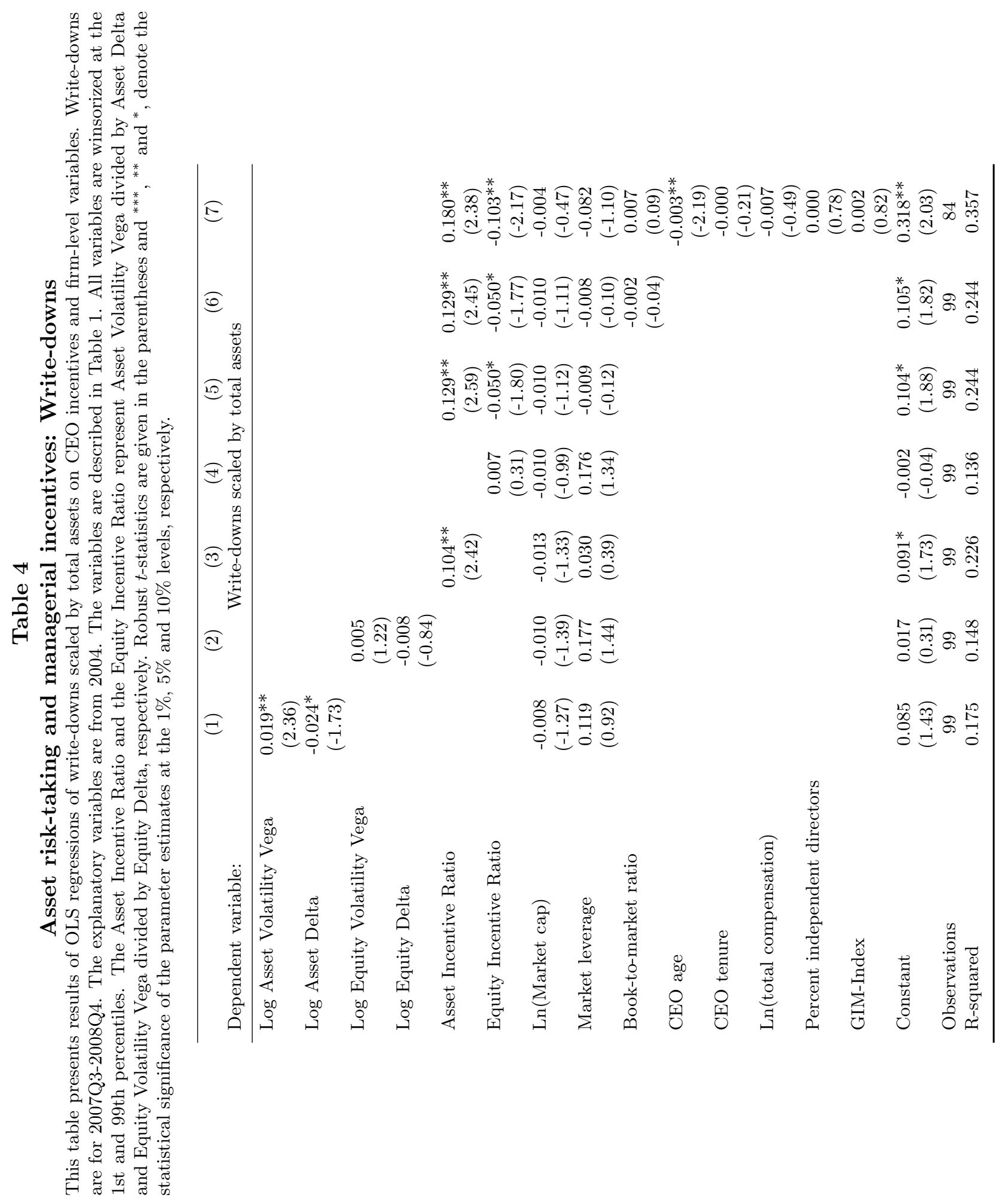




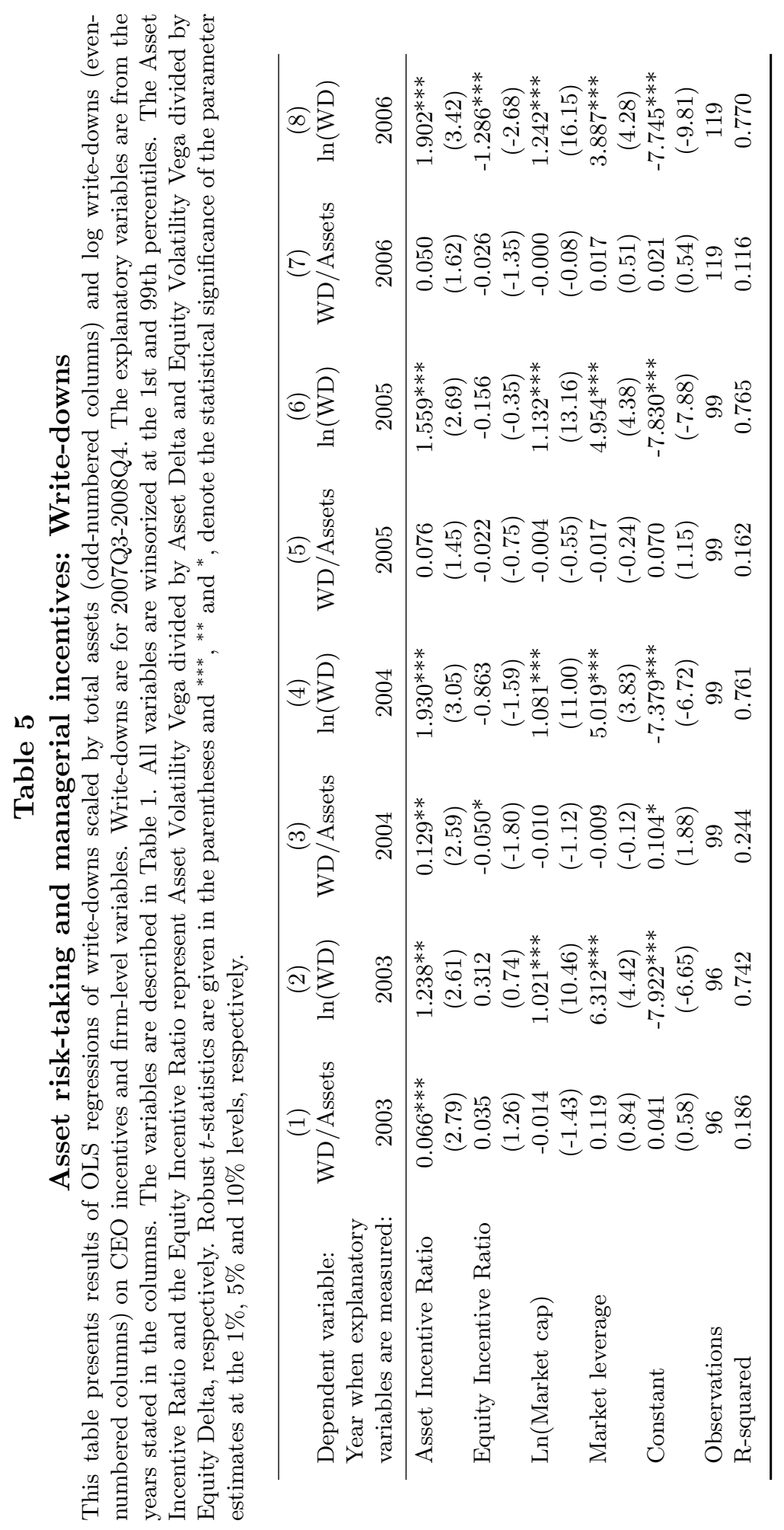




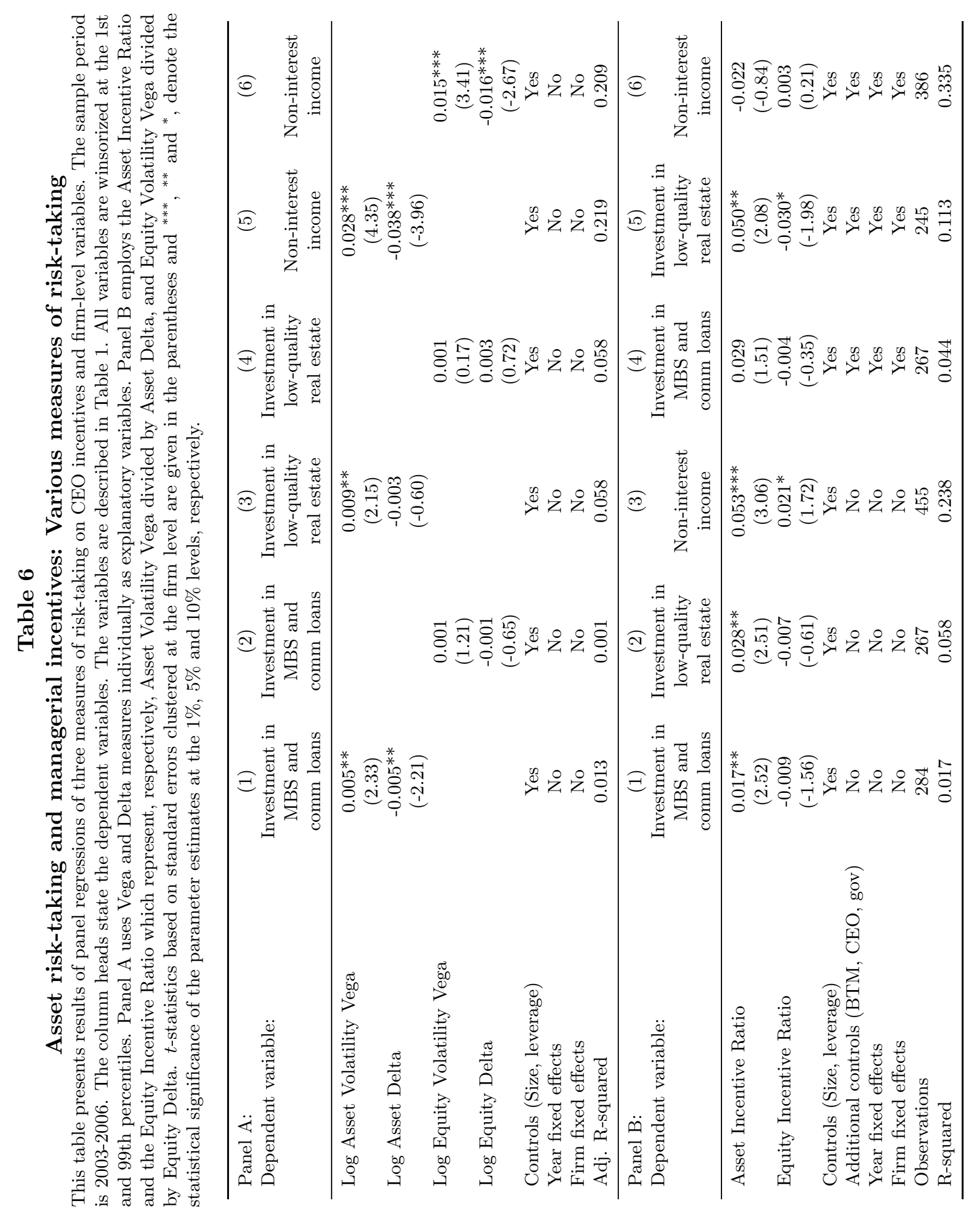




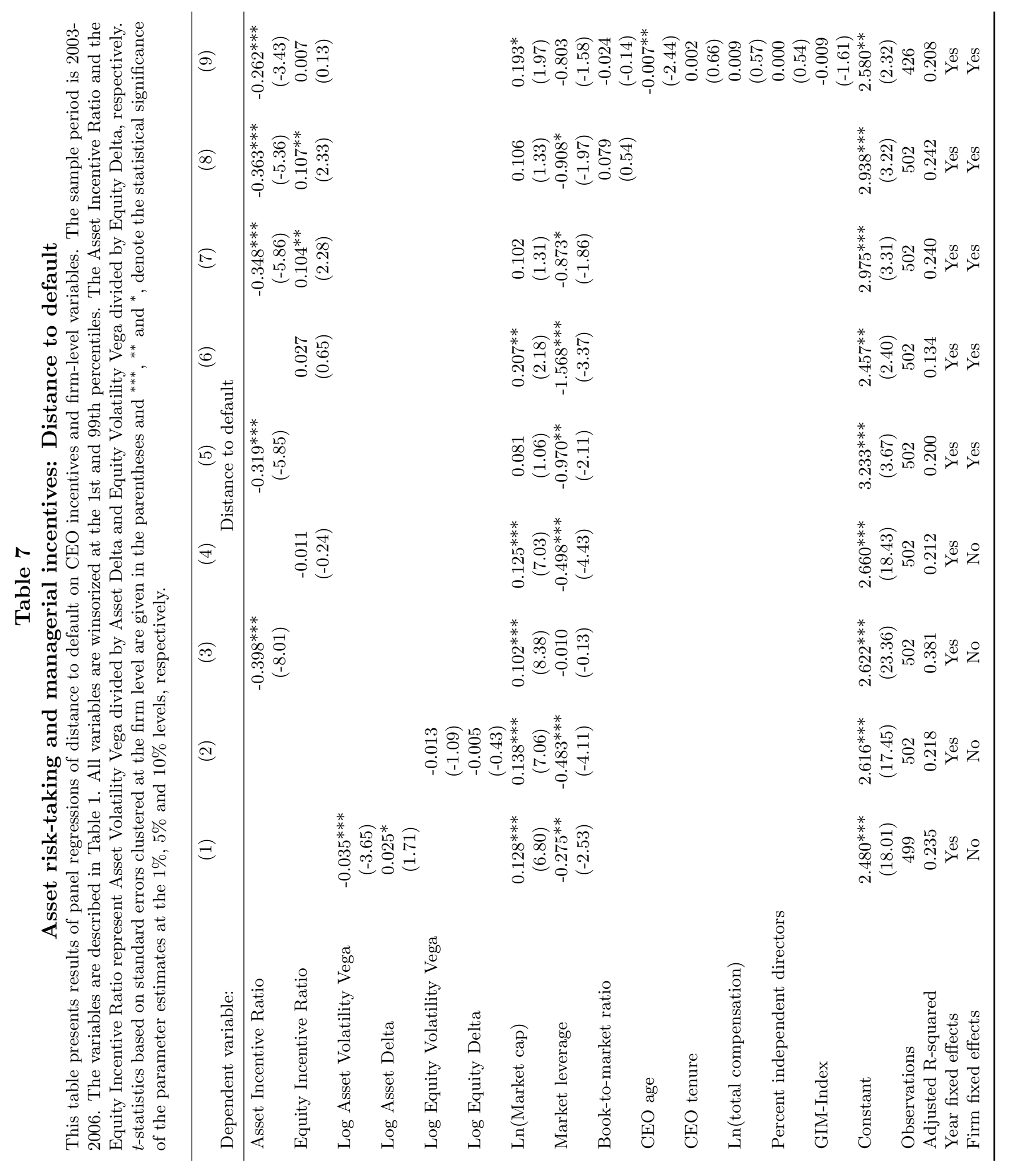




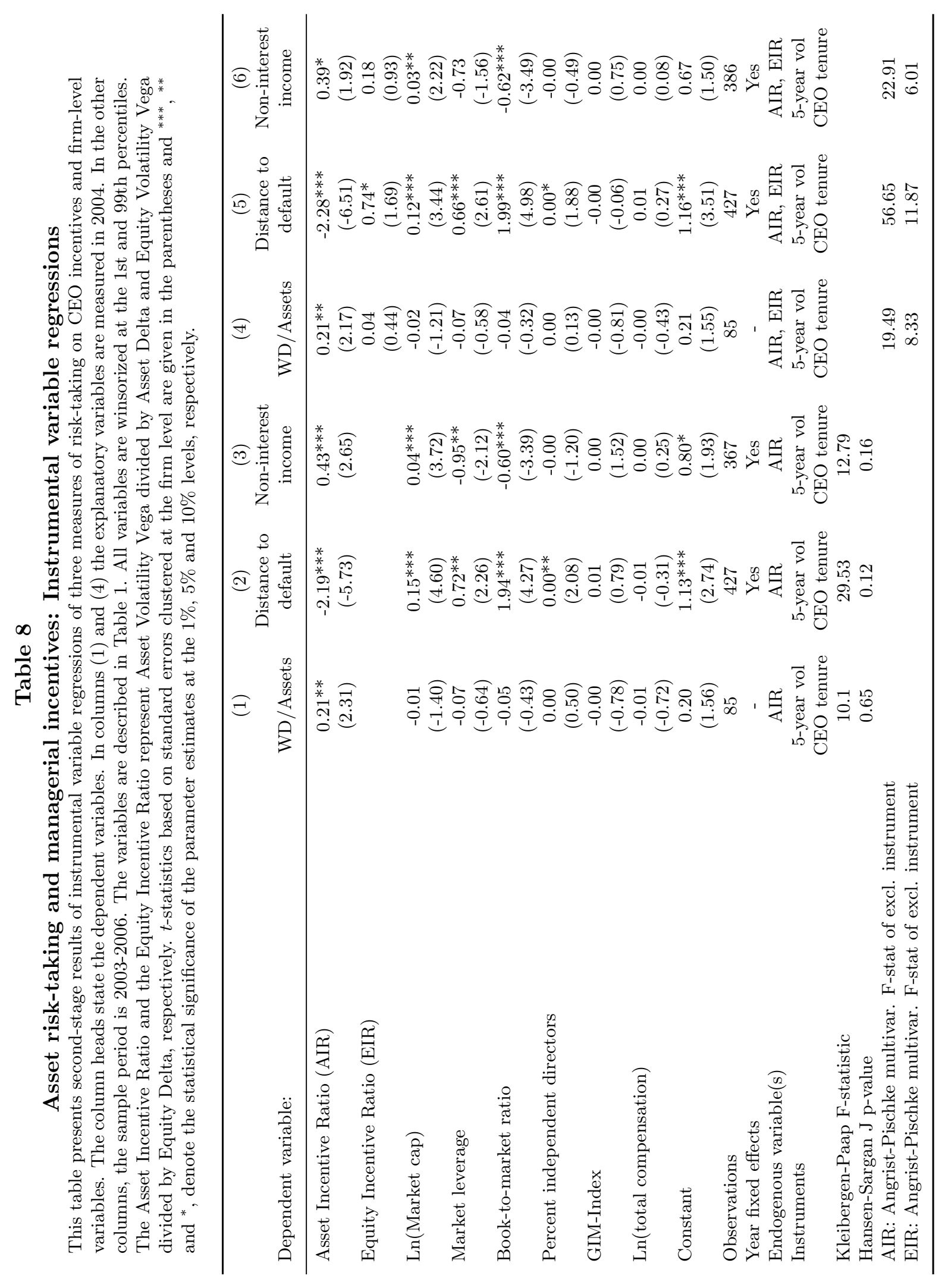


Supplementary Appendix

\section{Appendix A Asset Volatility Vega From Stock Options}

Consider the compound option pricing model described in Section 22.1. Our task is to calculate the sensitivity of the compound option pricing formula for a call option with respect to the underlying asset return volatility. Geske (1979) presents a formula for this derivative, which we denote by "Geske Vega,"

$$
\begin{aligned}
\text { Geske Vega } & =\frac{\partial C C\left(V, D, r, T_{C C}, T_{D}, \sigma_{V}, K\right)}{\partial \sigma_{V}^{2}} \cdot \frac{d \sigma_{V}^{2}}{d \sigma_{V}} \\
& =\frac{N_{2}\left(h+\sigma_{V} \sqrt{T_{C C}}, k+\sigma_{V} \sqrt{T_{D}}, \sqrt{T_{C C} / T_{D}}\right)}{N_{1}\left(k+\sigma_{V} \sqrt{T_{D}}\right)} D e^{-r T_{D}} \varphi(k) \sqrt{T_{D}}
\end{aligned}
$$

However, we do not rely on this formula for computing the Asset Volatility Vega we use in our analysis. Our motivation not to employ this formula is that the Black-Scholes model is a special case of the compound option model when the firm's debt, $D$, goes to zero (this observation is also noted by Geske $(1979)$ ). Indeed, in the limit as $D \rightarrow 0$, the compound option price converges to the Black-Scholes price. Therefore, we would also expect that, for zero debt, the Asset Volatility Vega from the compound option model should collapse into the formula for the Asset Volatility Vega (and, thus, in this special case the Equity Volatility Vega) from the Black-Scholes model. However, the formula for the Geske Vega suggests, counter-intuitively, that in the limit when $D \rightarrow 0$ the Asset Volatility Vega given by the compound option pricing model would converge to zero.

In Proposition 1, we derive the correct expression for the vega for a compound call option. 
Proof of Proposition 1. Taking the derivative of a call option in the compound option pricing model with respect to $\sigma_{V}$ gives us

$$
\begin{aligned}
\frac{\partial C C}{\partial \sigma_{V}} & =V\left(\left.\frac{\partial N_{2}\left(x, k+\sigma_{V} \sqrt{T_{D}} ; \sqrt{\frac{T_{C C}}{T_{D}}}\right)}{\partial x}\right|_{x=h+\sigma_{V} \sqrt{T_{C C}}} \cdot \frac{d\left(\sigma_{V} \sqrt{T_{C C}}\right)}{d \sigma_{V}}\right. \\
& \left.+\left.\frac{\partial N_{2}\left(h+\sigma_{V} \sqrt{T_{C C}}, y ; \sqrt{\frac{T_{C C}}{T_{D}}}\right)}{\partial y}\right|_{y=k+\sigma_{V} \sqrt{T_{D}}} \cdot \frac{d\left(k+\sigma_{V} \sqrt{T_{D}}\right)}{d \sigma_{V}}\right) \\
& +\left.D e^{-r T_{D}} \frac{\partial N_{2}\left(h, y ; \sqrt{\frac{T_{C C}}{T_{D}}}\right)}{\partial y}\right|_{y=k} \cdot \frac{d k}{d \sigma_{V}} \\
& +\left[\left.V \frac{\partial N_{2}\left(x, k+\sigma_{V} \sqrt{T_{D}} ; \sqrt{\frac{T_{C C}}{T_{D}}}\right)}{\partial x}\right|_{x=h+\sigma_{V} \sqrt{T_{C C}}}-K e^{-r T_{C C}} \frac{d N(h)}{d h}\right] \frac{d h}{d \sigma_{V}} . \\
& -\left.D e^{-r T_{D}} \frac{\partial N_{2}\left(x, k ; \sqrt{\frac{T_{C C}}{T_{D}}}\right)}{\partial x}\right|_{x=h}-
\end{aligned}
$$

In Lemma 1 (see below), we show that the expression in the square bracket of the last term in Equation (13) equals zero. Moreover, inserting the remaining derivatives used in Lemma 1 into this equation we obtain the formula

$$
\begin{aligned}
\frac{\partial C C}{\partial \sigma_{V}} & =V\left[\varphi\left(h+\sigma_{V} \sqrt{T_{C C}}\right) N_{1}\left(\frac{k+\sigma_{V} \sqrt{T_{D}}-\sqrt{\frac{T_{C C}}{T_{D}}}\left(h+\sigma_{V} \sqrt{T_{C C}}\right)}{\sqrt{1-\frac{T_{C C}}{T_{D}}}}\right) \sqrt{T_{C C}}\right. \\
& \left.+\varphi\left(k+\sigma_{V} \sqrt{T_{D}}\right) N_{1}\left(\frac{h+\sigma_{V} \sqrt{T_{C C}}-\sqrt{\frac{T_{C C}}{T_{D}}}\left(k+\sigma_{V} \sqrt{T_{D}}\right)}{\sqrt{1-\frac{T_{C C}}{T_{D}}}}\right) \frac{d\left(k+\sigma_{V} \sqrt{T_{D}}\right)}{d \sigma_{V}}\right] \\
& -D e^{-r T_{D}} \varphi(k) N_{1}\left(\frac{h-\sqrt{\frac{T_{C C}}{T_{D}}} k}{\sqrt{1-\frac{T_{C C}}{T_{D}}}}\right) \frac{d k}{d \sigma_{V}}
\end{aligned}
$$

where

$$
\frac{d k}{d \sigma_{V}}=-\frac{k}{\sigma_{V}}-\sqrt{T_{D}} \quad \text { and } \quad \frac{d\left(k+\sigma_{V} \sqrt{T_{D}}\right)}{d \sigma_{V}}=-\frac{k}{\sigma_{V}}
$$

and where $\varphi$ denotes the standard normal probability density. Now simplifying terms and using that $V \varphi(k+$ $\left.\sigma_{V} \sqrt{T_{D}}\right)=D e^{-r T_{D}} \varphi(k)$ we obtain Proposition 1. 
Lemma 1. Given the model assumptions,

$$
Q:=\left.V \frac{\partial N_{2}\left(x, k+\sigma_{V} \sqrt{T_{D}} ; \sqrt{\frac{T_{C C}}{T_{D}}}\right)}{\partial x}\right|_{x=h+\sigma_{V} \sqrt{T_{C C}}}-\left.D e^{-r T_{D}} \frac{\partial N_{2}\left(x, k ; \sqrt{\frac{T_{C C}}{T_{D}}}\right)}{\partial x}\right|_{x=h}-K e^{-r T_{C C}} \frac{d N(h)}{d h}=0 .
$$

Proof of Lemma 1. By relying on the relation

$$
N_{2}(h, k ; \rho)=\int_{-\infty}^{h} \varphi(x) N_{1}\left(\frac{k-\rho x}{\sqrt{1-\rho^{2}}}\right) d x
$$

as given in Geske (1979) (pages 79-80) and from the symmetry between $k$ and $h$, we have the following relations

$$
\left.\frac{\partial N_{2}\left(x, k+\sigma_{V} \sqrt{T_{D}} ; \sqrt{\frac{T_{C C}}{T_{D}}}\right)}{\partial x}\right|_{x=h+\sigma_{V} \sqrt{T_{C C}}}=\varphi\left(h+\sigma_{V} \sqrt{T_{C C}}\right) N_{1}\left(\frac{k+\sigma_{V} \sqrt{T_{D}}-\sqrt{\frac{T_{C C}}{T_{D}}}\left(h+\sigma_{V} \sqrt{T_{C C}}\right)}{\sqrt{1-\frac{T_{C C}}{T_{D}}}}\right)
$$

and

$$
\left.\frac{\partial N_{2}\left(h+\sigma_{V} \sqrt{T_{C C}}, y ; \sqrt{\frac{T_{C C}}{T_{D}}}\right)}{\partial y}\right|_{y=k+\sigma_{V} \sqrt{T_{D}}}=\varphi\left(k+\sigma_{V} \sqrt{T_{D}}\right) N_{1}\left(\frac{h+\sigma_{V} \sqrt{T_{C C}}-\sqrt{\frac{T_{C C}}{T_{D}}}\left(k+\sigma_{V} \sqrt{T_{D}}\right)}{\sqrt{1-\frac{T_{C C}}{T_{D}}}}\right)
$$

and

$$
\left.\frac{\partial N_{2}\left(x, k ; \sqrt{\frac{T_{C C}}{T_{D}}}\right)}{\partial x}\right|_{x=h}=\varphi(h) N_{1}\left(\frac{k-\sqrt{\frac{T_{C C}}{T_{D}}} h}{\sqrt{1-\frac{T_{C C}}{T_{D}}}}\right)
$$

and

$$
\left.\frac{\partial N_{2}\left(h, y ; \sqrt{\frac{T_{C C}}{T_{D}}}\right)}{\partial y}\right|_{y=k}=\varphi(k) N_{1}\left(\frac{h-\sqrt{\frac{T_{C C}}{T_{D}}} k}{\sqrt{1-\frac{T_{C C}}{T_{D}}}}\right) .
$$

Moreover, we use that $V \varphi\left(h+\sigma_{V} \sqrt{T_{C C}}\right)=\bar{V} e^{-r T_{C C}} \varphi(h)$ where $\bar{V}$ is the solution to Equation (5). This 
gives us

$$
\begin{aligned}
& Q=\bar{V} e^{-r T_{C C}} \varphi(h) N_{1}\left(\frac{k+\sigma_{V} \sqrt{T_{D}}-\sqrt{\frac{T_{C C}}{T_{D}}}\left(h+\sigma_{V} \sqrt{T_{C C}}\right)}{\sqrt{1-\frac{T_{C C}}{T_{D}}}}\right)-D e^{-r T_{D}} \varphi(h) N_{1}\left(\frac{k-\sqrt{\frac{T_{C C}}{T_{D}}} h}{\sqrt{1-\frac{T_{C C}}{T_{D}}}}\right) \\
& \text { - } K e^{-r T_{C C}} \varphi(h) .
\end{aligned}
$$

Simplifying terms inside the standard normal distribution functions, we can write Equation 22 as follows

$$
Q=e^{-r T_{C C}} \varphi(h)\left[\bar{V} N_{1}\left(\bar{k}(\bar{V})+\sigma_{V} \sqrt{T_{D}-T_{C C}}\right)-D e^{-r\left(T_{D}-T_{C C}\right)} N_{1}(\bar{k}(\bar{V}))-K\right] .
$$

By again relying on Equation (5) and on the definition of $\bar{V}$, we know that the term in square brackets is zero. Thus, our result is obtained.

\section{Remarks to the proof of Proposition 1.}

In some cases, researchers may be interested in analyzing how the firm value where the option is precisely at the money, $\bar{V}$, varies as the asset volatility varies. That is, we would wish to compute the term $\frac{d \bar{V}}{d \sigma_{V}}$. Although the term $\frac{d h}{d \sigma_{V}}$, in which $\bar{V}$ features, plays no role in the proof of Proposition 1 (the terms in front of it cancel out), we present the derivations for computing this derivative here for completeness.

Define the following function

$$
f(x, y)=x N_{1}\left(k(x, y)+y \sqrt{T_{D}-T_{C C}}\right)-D e^{-r\left(T_{D}-T_{C C}\right)} N_{1}(k(x, y))-K,
$$

where

$$
\tilde{k}(x, y)=\frac{\log \left(\frac{x}{D}\right)+\left(r-\frac{y^{2}}{2}\right)\left(T_{D}-T_{C C}\right)}{y \sqrt{T_{D}-T_{C C}}} .
$$

Now, by relying on Equation (24) above we have that

$$
f\left(\bar{V}, \sigma_{V}\right)=0
$$

Since the function $f$ depends on $\sigma_{V}$ both through the direct effect but also indirectly through its effect on $\bar{V}$, we can consider the function $f$ as a function in these two variables. Writing up the dynamics using the chain-rule, we have

$$
d f\left(\bar{V}, \sigma_{V}\right)=\frac{\partial f}{\partial x}\left(\bar{V}, \sigma_{V}\right) d \bar{V}+\frac{\partial f}{\partial y}\left(\bar{V}, \sigma_{V}\right) d \sigma_{V}=0
$$


which equivalently can be written as

$$
\frac{d \bar{V}}{d \sigma_{V}}=-\frac{\frac{\partial f}{\partial y}\left(\bar{V}, \sigma_{V}\right)}{\frac{\partial f}{\partial x}\left(\bar{V}, \sigma_{V}\right)}
$$

We obtain

$$
\frac{d \bar{V}}{d \sigma_{V}}=-\frac{D e^{-r\left(T_{D}-T_{C C}\right)} \varphi(\bar{k}) \sqrt{T_{D}-T_{C C}}}{N_{1}\left(\bar{k}+\sigma_{V} \sqrt{T_{D}-T_{C C}}\right)}
$$

where

$$
\bar{k}=\tilde{k}\left(\bar{V}, \sigma_{V}\right) .
$$

Now it is straightforward to compute the term $\frac{d h}{d \sigma_{V}}$ in Equation 13 . From,

$$
h=\frac{\log \left(\frac{V}{V}\right)+\left(r-\frac{\sigma_{V}^{2}}{2}\right) T_{C C}}{\sigma_{V} \sqrt{T_{C C}}}
$$

we obtain

$$
\frac{d h}{d \sigma_{V}}=\frac{\overline{\frac{1}{V \sqrt{T_{C C}}}} \frac{D e^{-r\left(T_{D}-T_{C C}\right)} \varphi(\bar{k}) \sqrt{T_{D}-T_{C C}}}{N_{1}\left(\bar{k}+\sigma_{V} \sqrt{T_{D}-T_{C C}}\right)}-h}{\sigma_{V}}-\sqrt{T_{C C}}
$$

We rely on the formula in Proposition 1 to measure the CEO asset risk-taking incentives we apply in the analysis. Analogously to the Asset Volatility Vega from stocks we divide the expression in Proposition 1 by 100 so that it measures the sensitivity of the option price with respect to a 0.01 change in the underlying asset return volatility, as we did it with the Equity Volatility Vega.

To confirm the intuitive benchmark result mentioned above, consider the case when the debt, $D$, tends to zero. Then, since $\bar{V}$ tends to the strike $K$ and $k$ tends to $+\infty$ it is clear that

$$
\lim _{D \rightarrow 0} \frac{\partial C C}{\partial \sigma_{V}}=V \varphi\left(h+\sigma_{V} \sqrt{T_{C C}}\right) \sqrt{T_{C C}}
$$

which is precisely the vega of a call option in the Black-Scholes model and where $h$ is given in Equation (31).

Figure A-1 shows a comparison of the formulas for the Asset Volatility Vega given by the formula in Geske (1979) (see Equation (12) with our Asset Volatility Vega (see Proposition 1) and the one computed by the first difference approximation for parameter values relevant for the analysis conducted in this paper and for varying levels of asset volatilities, $\sigma_{V}$.

Supplementary Appendix Page - 5 


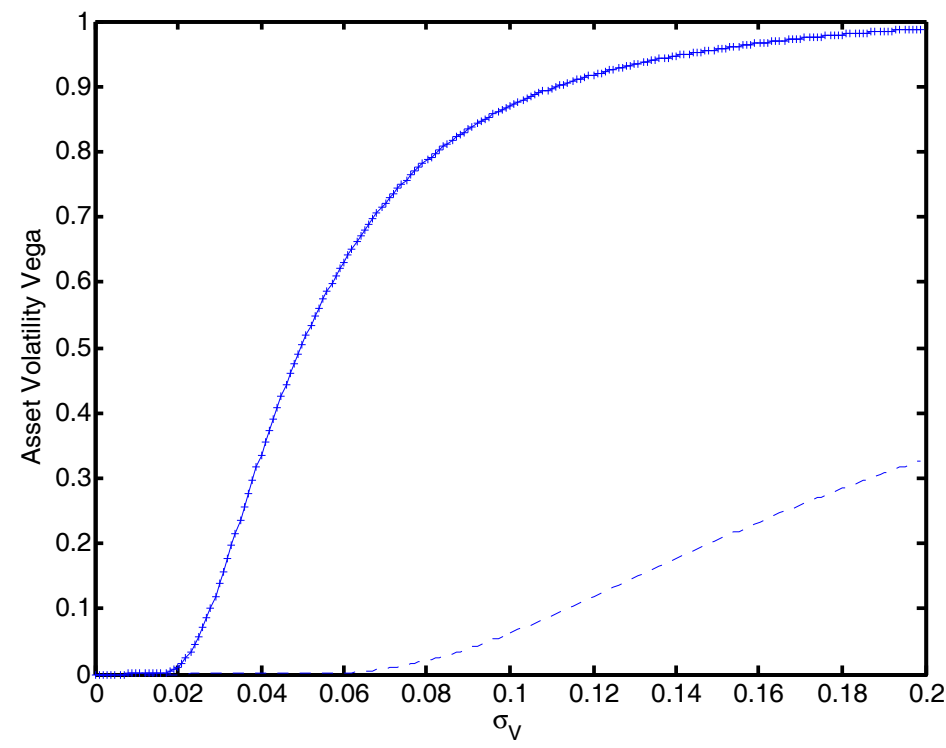

Figure A-1

Comparison of Asset volatility Vega to Geske's formula.

Comparison of Asset Volatility Vegas for varying asset volatility, $\sigma_{V}$, computed using three different approaches: The Geske approach (dotted line), our approach ("+") and the difference approximation (solid line). The parameters are $V=100, K=50, r=0.04, T_{D}=10, T_{C C}=6$ and $D=85 . \Delta=10^{-11}$ is used to calculate the difference approximation.

We make two observations. First, as before, the analytical formula in given in Proposition 1 completely agrees with the first difference approximation. Second, there are substantial differences between the Asset Volatility Vega computed using the formula in Proposition 1 and the formula presented in Geske (1979) at common levels of the asset volatility. The difference (both in absolute and in relative terms) between the two approaches to compute the Asset Volatility Vega is particularly pronounced for moderate and low levels of asset volatility, which is commonly observed for financial institutions, though it remains substantial even at higher levels of asset volatility. That is, if we were to use the formula in Geske (1979), we would substantially underestimate the incentives to take asset risk as compared to our formula (and the difference approximation).

\section{Appendix B Equity Delta and Equity Volatility Vega}

Following Core and Guay (2002), we calculate Equity Delta and Equity Volatility Vega using the derivatives of the Black-Scholes formula (see Black and Scholes (1973)) with respect to the underlying stock and the 
stock return volatility respectively. We assume that the stock price, $S$, follows a geometric Brownian motion

$$
\frac{d S_{t}}{S_{t}}=\mu_{S} d t+\sigma_{S} d W_{t}
$$

under the historical measure. The parameters $\mu_{S}$ and $\sigma_{S}$ are assumed constant and we also assume that there exists a bank account which yields a constant interest rate $r$. Recall that the value of a plain vanilla call is given by

$$
B S=S e^{-\delta T} N\left(d_{1}\right)-K e^{-r T} N\left(d_{2}\right)
$$

with

$$
\begin{aligned}
d_{1}\left(S, K, r, T, \sigma_{S}\right) & =\frac{\ln (S / K)+\left((r-\delta)+\sigma_{S}^{2} / 2\right) T}{\sigma_{S} \sqrt{T}} \\
d_{2}\left(S, K, r, T, \sigma_{S}\right) & =d_{1}\left(S, K, r, T, \sigma_{S}\right)-\sigma_{S} \sqrt{T}
\end{aligned}
$$

where $N$ denotes the cumulative distribution function of a standard normal random variable. $S$ denotes the stock, $K$ denotes the strike, $\sigma_{S}$ is the return volatility, $r$ represent the risk-free rate, $\delta$ denotes the dividend yield and $T$ represents the maturity of the option. $T$ corresponds to $T_{C C}$ in the Compound option pricing framework.

The Equity Delta of a single option can be computed according to

$$
\text { Equity Delta }=\frac{\partial B S}{\partial S} \cdot(S / 100)=e^{-\delta T} N\left(d_{1}\right) \cdot(S / 100)
$$

which measures the sensitivity of the option value with respect to a one percent change in the stock price.

The Equity Volatility Vega of a single option can be computed according to

$$
\text { Equity Volatility Vega }=\frac{\partial B S}{\partial \sigma_{S}} \cdot(1 / 100)=e^{-\delta T} \varphi\left(d_{1}\right) S \sqrt{T} \cdot(1 / 100)
$$

which measures the sensitivity of the option value with respect to a 0.01 change in the underlying stock return volatility and $\varphi$ denotes the density of a standard normal random variable.

As is standard in the literature, we assume that Equity Delta from stocks is equal to one (by construction) and that Equity Volatility Vega from stocks equals zero; see Guay (1999).

\section{Supplementary Appendix Page - 7}




\section{Appendix C Sample and Parameter Choices}

Table C-1 shows the SIC codes we consider in the analysis. As described in the main text, we mostly follow Guay (1999) in our parameter choices. Table C-1 shows descriptive statistics for all the relevant variables.

To obtain an estimate of the firm value return volatility, $\sigma_{V}$, Guay (1999) proposes to rely on portfolio theory. Thus, the variance of the firm value can written as

$$
\sigma_{V}^{2}=X_{\text {debt }}^{2} \sigma_{\text {debt }}^{2}+X_{\text {equity }}^{2} \sigma_{\text {equity }}^{2}+2 X_{\text {debt }} X_{\text {equity }} \operatorname{Cov}\left(\sigma_{\text {debt }}, \sigma_{\text {equity }}\right)
$$

where $X_{\text {debt }}$ and $X_{\text {equity }}$ are the weights of debt and equity in the firm's capital structure and $\sigma_{\text {equity }} \equiv \sigma_{S}$ is the annualized standard deviation of daily log stock returns. We use the same $\sigma_{\text {equity }}$ as we have used for computing Equity Volatility Vega and Equity Delta. For $\sigma_{\text {debt }}$, we use the annualized standard deviation of monthly (log) returns using the Merrill Lynch Bank of America corporate financial bond index using a five year period. Moreover, we follow Guay (1999) and set the correlation between equity and debt returns equal

to one, $\operatorname{Corr}\left(\sigma_{\text {debt }}, \sigma_{\text {equity }}\right)=\frac{\operatorname{Cov}\left(\sigma_{\text {debt }}, \sigma_{\text {equity }}\right)}{\sqrt{\sigma_{\text {debt }}^{2} \sigma_{\text {equity }}^{2}}}=1$, which implies that $\operatorname{Cov}\left(\sigma_{\text {debt }}, \sigma_{\text {equity }}\right)=\sigma_{\text {debt }} \sigma_{\text {equity }}$ and, therefore,

$$
\sigma_{V}^{2}=X_{\text {debt }}^{2} \sigma_{\text {debt }}^{2}+X_{\text {equity }}^{2} \sigma_{\text {equity }}^{2}+2 X_{\text {debt }} X_{\text {equity }} \sigma_{\text {debt }} \sigma_{\text {equity }} .
$$




\section{Table C-1}

\section{Industry classification.}

SIC code 6211 includes some well-known investment banks and some brokers. In general, where we have data on risk-taking measures we keep these brokerage firms in the sample but exclude those brokers listed in the same SIC code as exchanges, SIC code 6200 . While engagement in the subprime mortgage business may not have been at the core of the business strategy of those brokers in the SIC 6211 code, these companies nonetheless often did engage in such activities. Our write-down regression results (Table 4 hold also if we exclude all SIC 6211 firms, but this then also excludes firms such as Bear Stearns, Goldman Sachs, Merrill Lynch, and Morgan Stanley, clearly an undesirable sample restriction. We do not consider investment advisors (SIC code 6282). For other finance SIC codes that are not shown we do not have companies with compensation data. For some dependent variables (non-interest income, investments in MBS and commercial loans) only bank-holding companies reporting to the Federal reserve (SIC codes $6020,6035,6036)$ are included in the sample.

\begin{tabular}{lccl} 
Financial institutions & 2-digit SIC & SIC Code & Financial Service Industry \\
\hline Depository Institutions & 60 & 6020 & Commercial Banks \\
& & 6035 & Federal Savings Institutions \\
& & 6036 & Savings Institutions, Except Federal \\
& 61 & 6111 & Federal Credit Agencies \\
Nondepository Credit & & 6141 & Personal Credit Institutions \\
Institutions & & 6159 & Miscellaneous Business Credit \\
& & 6162 & Mortgage Bankers and Loan Correspondents \\
& & 6172 & Finance Lessors \\
& 62 & 6211 & Security Brokers and Dealers \\
\hline Security Brokers and Dealers & 62 & & Finance Services \\
\hline
\end{tabular}




\section{Table C-1}

\section{Estimated parameters for the Compound option pricing model}

Descriptive statistics of the parameters used in the computations of Asset Volatility Vega and Asset Delta. The summary statistics are average over the years 2003-2006. Per-share stock price denotes the average end-of-year stock price. Per-share book-value of debt denotes the book value of liabilities end-of-year. The risk-free interest rate is the yield on U.S. Treasury bonds with a maturity similar to maturity of the firms liabilities. Standard deviation of debt returns is the annualized standard deviation calculated on monthly (log) returns using the Merrill Lynch Bank of America corporate financial bond index using a five year period. Standard deviation of equity returns is calculated (from CRSP data) as the annualized standard deviation of daily log-returns over the past three years up to each year in our sample by assuming 250 trading days in the year. Est. std. dev. of returns on firm value denotes the estimated standard deviation of returns on the firm value. Weight of equity and Weight of debt are, respectively, the shares of equity and debt in the firm's capital structure. Implied per-share market value of assets is backed out using the Black-Scholes equation. Per-share market value of assets denotes sum of the per share end-of-year stock price and the per share book value of debt. Price-to-strike ratio is the implied per share firm value divided by the per share book value of debt. The variables are winsorized at the 1st and 99th percentiles on an annual basis. The term "q" denotes the quantile, i.e., 10q refers to the 10th percentile in the empirical distribution of the respective variable. All monetary values are expressed in 2008 dollars.

\begin{tabular}{lrrrrrrr} 
Firm characteristics & Mean & Std. Dev. & $10 \mathrm{q}$ & $25 \mathrm{q}$ & $50 \mathrm{q}$ & $75 \mathrm{q}$ & $90 \mathrm{q}$ \\
\hline Per-share stock price (\$) & 42.0 & 22.7 & 17.9 & 25.6 & 37.3 & 52.8 & 69.6 \\
Per-share book-value of debt (\$) & 238.3 & 254.3 & 61.2 & 103.9 & 160.4 & 282.4 & 409.7 \\
Risk-free interest rate (\%) & 4.1 & 0.4 & 3.7 & 3.9 & 4.3 & 4.6 & 4.6 \\
Standard deviation of debt returns (\%) & 3.1 & 0.1 & 2.9 & 2.9 & 3.0 & 3.2 & 3.2 \\
Standard deviation of equity returns (\%) & 27.5 & 9.5 & 17.3 & 21.3 & 25.8 & 32.0 & 37.8 \\
Est. std. dev. of returns on firm value (\%) & 5.7 & 2.8 & 4.0 & 4.5 & 5.1 & 5.9 & 7.1 \\
Weight of equity (\%) & 10.4 & 6.9 & 5.6 & 7.4 & 9.0 & 10.5 & 14.3 \\
Weight of debt (\%) & 89.4 & 7.9 & 85.6 & 89.4 & 91.0 & 92.6 & 94.4 \\
Imp. per-share market value of assets (\$) & 215.6 & 200.4 & 67.1 & 108.1 & 156.9 & 256.0 & 373.3 \\
Per-share market value of assets (\$) & 280.0 & 270.4 & 85.2 & 134.2 & 201.4 & 333.4 & 476.3 \\
Price-to-strike ratio & 1.1 & 0.8 & 0.8 & 0.9 & 1.0 & 1.1 & 1.2 \\
\hline
\end{tabular}

